NOTICE: this is the author's version of a work that was accepted for publication in the Journal of Banking and Finance. Changes resulting from the publishing process, such as peer review, editing, corrections, structural formatting, and other quality control mechanisms may not be reflected in this document. Changes may have been made to this work since it was submitted for publication. A definitive version was subsequently published in Journal of Banking and Finance, Vol.49, (2014)]. DOI: 10.1016/j.jbankfin.2014.09.006 


\title{
News Sentiment in the Gold Futures Market
}

\author{
Lee A. Smales, CFA \\ School of Economics \& Finance \\ Curtin University \\ Building 402 \\ Kent Street \\ Perth \\ WA 6845 \\ Australia \\ lee.smales@curtin.edu.au
}

This article utilises commodity specific news sentiment data provided by Thomson Reuters News Analytics to examine the relationship between news sentiment and returns in the gold futures market over the period 2003-2012. There is an asymmetric response to news releases with negative news sentiment invoking a greater contemporaneous response in returns of gold futures than positive news. There is evidence to support the supposition that net trader positions significantly impacts the identified sentiment relationship with effect greatest when traders are holding positions contrary to their natural position; this may be explained by constraints imposed on traders in terms of credit availability, exchange imposed limits, or inventory required for physical settlement. Recession, and associated changes in credit costs, impacts the size of net positions and the news sentiment / return relationship.

Keywords: News sentiment; Futures Markets; Trading Behaviour; Gold; COMEX; Information JEL Codes: G10; G14 


\section{Introduction}

Gold has played an important role in the global financial system for millennia, utilized as a store of value and a means of exchange. Traditionally, investors have used gold as a hedge against inflation while from a portfolio management perspective it can be seen to offer diversification benefits (Sherman, 1982; McCown and Zimmerman, 2006; Draper et al., 2006) and protection against exchange-rate risk for investors with U.S. dollar holdings (Capie et al., 2005). Academic work (Baur and Lucey, 2010; Baur and McDermott, 2010) and the financial media have indicated the importance of gold as a safe haven during times of market turmoil. Such interest, together with the development of markets such as that for exchange traded funds (ETFs), has resulted in a large, and growing, number of institutional and retail investors participating in the gold market. Gold demand for investment purposes now constitutes approximately 1,525 tonnes per annum ${ }^{1}$ (35\% of total demand). Erb and Harvey (2013) note that while the price of gold is historically high, it may rise further if trends in emerging markets match those in the developed world. Recent media reports on the large holdings of gold assets by hedge funds, and the spectacular gains and losses witnessed in those funds ${ }^{2}$, suggest that it is of some importance to understand how such markets respond to news events.

Much of the extant literature in the field of the news impact on asset prices has focused on specific and easily identifiable news events, such as macroeconomic announcements and earnings results, where the news effect is readily quantifiable; this is at least partly due to the difficulty in applying quantitative techniques (Mindell, 1961) in the era prior to accessible computing power. Chan (2003) and Antweiler and Frank (2004) use more comprehensive datasets to study the effect of news on stock returns, reporting a statistically significant effect on returns. Tetlock (2007) begins the process of assigning quantitative scores to the sentiment of text in news releases and finds that high levels of media pessimism predict declining market prices which are followed by a price reversion. Using a similar methodology, Engelberg (2008) and Tetlock et al. (2008) find that the proportion of negative words in a news story forecasts firm earnings. Sinha (2011) constructs a measure to predict future returns while Engleberg et al. (2012) find that the negative relationship between short sales and future returns is significantly stronger in the presence of news stories containing negative news.

\footnotetext{
1 Source: World Gold Council - Gold Demand Trends

${ }^{2}$ For example: http://www.bloomberg.com/news/2013-07-08/paulson-s-pfr-gold-fund-fell-23-in-june-65this-year.html
} 
Advances in technology have enabled the development of news analytics software packages such as Thomson Reuters News Analytics ${ }^{3}$ (TRNA) and Ravenpack which utilize advanced algorithms to assign sentiment indicators to newswire releases in real-time have allowed a more comprehensive quantitative examination of the effect of news contrary to the expectations of Mindell (1961). Using news sentiment measures derived from such software, Leinweber and Sisk (2011), Groß-Klußmann (2011), and Smales (2012) identify distinct response in returns and volatility in various international stock markets, , after filtering out noise according to indicated relevance. Dzielinski (2012) notes that while negative news resolves asymmetric information on average, positive news does not. To-date the impact of non-scheduled news outside of the equity market context has been ignored, largely because much of the data is based on firm-specific news.

Mindell (1961) states that financial markets "often respond differently to the same type of news on different occasions". Kandel and Stambaugh (1990) and Veronesi (1999) suggest that the difference in the response to news is dependent on the business cycle. Hamilton and Lin (1998) note that recession is the primary factor that drives fluctuations in the volatility of stock returns. Most recently, Garcia (2013) studies the effect of sentiment on stock prices during the $20^{\text {th }}$ century and identifies that the predictability of returns using news content is concentrated in recessions. Since gold is often viewed as a safe haven in times of economic crisis, it is pertinent to consider the state of the business cycle when examining the impact of news on gold prices.

Commitments of Traders (COT) reports have been published by the Commodity Futures Trading Commission (CFTC) on a monthly basis since 1962, and on a weekly basis since 2000. The reports have allowed academics and market participants to develop an understanding of how the positioning and inventory of various trader types may help to explain market prices and risk premiums. Chang (1985) employs a nonparametric procedure to find that the net positioning of large speculators has some predictive power in forecasting price rises in agricultural futures. Bessembinder (1992) finds support for hedging pressure as a determinant of futures premiums such that returns in futures markets vary with the net holdings of large hedgers. Wang (2001, 2003a,2003b) constructs trader position-based sentiment measures in various futures markets and finds significance in predicting market returns. This work has largely focused on agricultural, equity index and foreign currency futures; with the increasing importance of gold prices to the

\footnotetext{
${ }^{3}$ Formerly titled Thomson Reuters NewsScope Sentiment Engine (RNSE)
} 
portfolio returns of investors it is appropriate to extend this analysis. It is also possible that the identified predictive power of trader types may come from exploiting the cyclical nature of commodity prices rather than forecasting news events and so it is of interest to investigate the source of this performance.

This article contributes to the literature in several important ways. Firstly, this is the first study of the influence of news sentiment on market returns that does not utilise firm-specific data. Secondly, the extant work on the impact of news events in equity markets is extended to a rapidly expanding asset class that is appearing in the diversified portfolios of many investors; it is salient for such investors to have an understanding of how news events will impact returns. Third, since one of the primary reasons that many investors add gold to their portfolios is the perceived safe haven quality it is important to understand how the relationship with news evolves with respect to underlying macroeconomic conditions, particularly during times of economic turmoil such as occur in recession. Finally, the literature on the impact of market positioning is extended to consider the gold futures market and the potential influence of such positioning on the reaction to news events; this may allow investors to identify points in time when investing in gold futures will have potentially large gains or losses as a result of news.

The principle results suggest that there is an asymmetric response to news releases with negative news sentiment invoking a greater response in returns of gold futures than positive news. The business cycle influences the news / return relationship with news sentiment having a greater impact during the financial crisis related recession of 2007-2009. The asymmetry effect is reversed during this period with the less frequent positive news having a greater impact on returns than negative news. Consistent with models of inventory control and hedging pressure, there is evidence to support the supposition that market positioning significantly impacts the relationship between news releases and market returns. This effect is greatest when traders are holding inventory contrary to their natural position, and this may be partly explained by the inability of hedgers to forecast news events, particularly the inability to forecast negative news when they are least hedged. The results have implications for academics and market practitioners seeking to validate news analytics software and understand the relationship between news sentiment and market movements. The results may also be of interest to investors who wish to understand how market positioning may influence or predict future returns, and how returns may be impacted under changing macroeconomic environments. 
The remainder of this paper is organized as follows: Section 2 provides some background as to the extant literature and develops several hypotheses that may be empirically tested. Section 3 discusses the nature of the data used in this paper, with a particular focus on the news sentiment measure. Section 4 presents empirical testing of the basic relationship between news sentiment and returns in the gold derivatives market, and the impact of economic conditions. Section 5 considers the influence of market positioning on that relationship. Section 6 concludes the paper.

\section{Background and Hypothesis Development}

Roll (1988) and Cutler et al. (1989) find that quantitative measures such as macroeconomic announcement and earnings surprise do not explain the majority of asset returns; it is possible that qualitative variables such as sentiment from news articles may go some way to understanding other explanatory factors in asset returns. Brooks et al. (2003) find that only new and unpredictable information moves prices, while Kalev et al. (2004) find that news arrival has a positive and significant impact on the conditional variance of stock returns. However, it was not until Tetlock (2007) that a concerted effort was made to quantify the tone and sentiment of text; information that is essentially qualitative in nature in its raw form. Tetlock (2007) utilizes the General Inquirer to categorize words in a Wall Street Journal column and assigns a sentiment score to articles. Consistent with theoretical models of noise and liquidity traders, the study finds that negative stories predict low market returns. Tetlock (2008) argues that the linguistic content of news messages captures hard-to-quantify aspects of fundamentals which are quickly impounded into stock prices. Groß-Klußmann (2011) and Smales (2012) consider the news event reaction of stock markets in the UK and Australia respectively. Both studies show that the classification of news according to indicated relevance is crucial to filter out noise and to identify significant effects. Dzielinski (2011) shows that US stock markets react to news in the appropriate way such that positive (negative) news days have above-average (below-average) returns.

The possibility that investors may overreact to unexpected and dramatic news events has been identified in the extant literature (De Bondt and Thaler, 1985; Brooks et al., 2003; Ederington and Lee, 1995) and creates the potential for profitable trading opportunities. Chan (2003) examines monthly returns of US stocks following public news events and finds that investors overreact to news shocks, causing excess trading volume and leading to reversal. Tetlock (2007) finds that the downward pressure on prices induced by media pessimism is subsequently reversed. 
Evidence of an asymmetric reaction to positive and negative news, such that negative news has a greater impact, has been noted in a number of stock market studies. Tetlock et al. (2008) report that negative words in news articles are able to forecast low firm earnings and thus impact the stock price. Leinweber and Sisk (2011) and Smales (2012) find that the reaction to negative news is more vigorous and thus negative sentiment signals are more exploitable. Riordan et al. (2013) study the impact of newswire messages on price discovery in the Toronto Stock Exchange and report that negative news messages are associated with higher adverse selection costs, are more informative, and induce stronger market reactions. Dzielinski (2012) finds that negative news resolves information asymmetry while positive news does not; suggesting that this result may be explained by positivity bias such that on average news articles are biased to present positive company news. One possible explanation for the asymmetric news effect lies in behavioural finance and in particular the suggestion of Kahneman and Tversky (1979) that market participants are loss-averse, and so prefer avoiding losses to acquiring gains.

The first hypothesis seeks to extend prior work on news sentiment in stock markets to the market for gold derivatives.

Hypothesis 1: The gold futures market reacts to highly relevant news with a stronger reaction in the presence of negative news; larger returns in the presence of negative market news would be consistent with gold acting as a safe haven.

It is possible that the state of the business cycle has an impact on how asset prices respond to news events. McQueen and Roley (1995), Jensen et al. (1996) and Boyd et al. (2005) report that business conditions have an influence on security returns as a result of the associated monetary environment. Veronesi (1999) indicates that the difference in the response of asset prices to news is dependent on the state of the business cycle. Bessembinder (1992) and Bessembinder and Chan (1992) document that macroeconomic variables known to possess forecast power in equity and bond markets also possess forecast power in futures markets. Recent work has identified an asymmetric relationship such that news releases have a greater impact during times of recession. Hamilton and Lin (1998) note that recession is the primary factor that drives fluctuations in the volatility of stock returns. Dzielinski (2011) identifies a news premium and suggests that this primarily relates to the high impact of news in situations of general uncertainty that accompany recession and financial crisis; a result of investors paying more attention to news reports during crisis periods. Garcia (2013) examines the effect of news sentiment on stock prices throughout the 
$20^{\text {th }}$ century and reports that the predictability of stock returns using news content is concentrated in recessions. In a similar vein to Dzielinski (2011), Garcia (2013) suggests that the findings are a consequence of recession inducing heightened investor sensitivity to news owing to the emotional impact on decision making.

The second hypothesis relates to the work on the effect of the business cycle on the response of asset prices to news releases. Given the assertion by authors such as Draper et al. (2006), Baur and Lucey (2010) and Baur and McDermott (2010) that gold is a safe haven in times of economic turmoil, such as that accompanying the Global Financial Crisis (GFC) and European sovereign debt crisis, it is likely that investors will increase their holdings of gold at such times; therefore it is particularly relevant to investigate how news releases will impact returns.

Hypothesis 2: Consistent with the prior work on stock markets, the business cycle will impact the sensitivity of the gold futures market to relevant newswire messages. In particular, the recessionary period surrounding the market turmoil of the global financial crisis (GFC) will result in an increased sensitivity to news releases.

Extreme positioning in financial markets, particularly futures markets, is often a newsworthy even in itself ${ }^{4}$, and it is possible that market positioning may have an impact on how assets react to relevant news. Brown and Cliff (2005) suggest that excessive optimism drives prices away from fundamental values, and periods of high sentiment should be followed by low returns; this is consistent with the idea that extreme positioning in the futures market (long or short) will result in subsequent losses. The issue of market positioning is analogous to the inventory control models developed by Garman (1976), Stoll (1978), and Amihud and Mendelson (1980) which are discussed in Madhavan (2000). Such models suggest that if inventory is important then dealers who are already long may not be able to take on additional inventory without dramatic price reductions. In much the same way, futures traders who are already long (or short) may not be able to respond to positive (negative) news by adding to their position owing to capital constraints or imposed risk limits. As returns may be driven by buying (selling) pressure in response to positive (negative) news capital constraints will impact potential returns; thus future returns may fall as position size increases. Indeed, one may expect that capital constraints may result in possible large-scale inventory adjustments and price reversals as noise traders, detailed by Bagehot

\footnotetext{
${ }^{4}$ For instance: http://www.bloomberg.com/news/2013-07-24/blackrock-sees-aussie-at-80-cents-aftershort.html
} 
(1971) and Black (1986), search for liquidity in light of news releases that are contrary to their positioning. As speculators are generally subject to higher margin requirements than those imposed on hedgers one may expect capital constraints to have more impact when the position of speculators becomes large.

Since the size of outstanding trading positions may have an impact on the market response to news it is of interest to consider whether different trader types possess any form of superior forecasting ability. Chang (1985) and Wang (2001, 2003a, 2003b, 2004) utilize COT data to investigate this issue in the market for agricultural futures, stock index futures, and currency futures. The general finding is that trades of speculators (hedgers) are positively (negatively) correlated with future returns, although at least some of the profits are compensation for risk. Wang (2004) finds that this relationship is stronger for extreme trader sentiment. However, there is no insight as to whether traders are able to forecast forthcoming news events.

The final hypothesis considers how the market response to newswire messages, and the sentiment of those messages, is affected by market positioning. This analysis would be particularly relevant to investors considering gold investments at times of extreme market positioning as they may need to adjust expectations around volatility of returns.

Hypothesis 3: Extremely large inventory positions of traders result in an adjustment to the relationship between news sentiment and the returns from gold futures.

\section{Data}

\subsection{Data on News Sentiment Indicators}

News sentiment data for the period $2^{\text {nd }}$ January $2003-31^{\text {st }}$ October 2012 is obtained from Thomson Reuters News Analytics (TRNA; an algorithmic text-reading tool provided by SIRCA ${ }^{5}$ ). Previously, news analytics software has focused on firm-specific news with the result that the literature has focused on equity markets and ignored the impact of non-scheduled newswire events in other important markets. However, TRNA now provides additional data to enable the study of news sentiment outside of the equity market context. The TRNA data set describes each news item with more than 40 pieces of metadata, with the most important in the context of this investigation been:

5 Securities Industry Research Centre of Asia-Pacific 
- Identifier of the commodity mentioned in the news;

- Timestamp, indicating the arrival of the news article to precision of 1-second;

- Sentiment, a discrete variable indicating whether the news was positive $(+1)$, neutral $(0)$ or negative (-1). This measure is based on a purely linguistic analysis of text and does not contain any form of market feedback.

- Sentiment probabilities, a set of variables which shows the probability of assigning each of the possible sentiment indicators to the news item, with the indicator assigned to the variable with the highest probability. Intuitively, a news item with a positive news probability of 0.8 can be seen as more positive than one with a probability of 0.2 .

- Relevance, a continuous variable on the $[0,1]$ interval indicating how prominently the commodity was mentioned in the news article. A relevance score of 1 generally indicates that the commodity was mentioned directly in the headline.

- Novelty, which shows whether the news item is linked to other similar news items or is an item in a sequence of updated news items. In order to ensure that analysis focuses on the arrival of new information, items with a Linked Count greater than 0 or a Sequence Number greater than 1 are excluded from the sample.

An example of a positive news event would be the message broadcast at 14:02:44 on $4^{\text {th }}$ June 2008 - "Gold to hit record above $\$ 1,000$ per oz this year". A negative sentiment score was attached to the broadcast text "Asian shares fall as Eurozone yields rise" on 15 11:00:48. Groß-Klußmann and Hautsch (2011) and Smales (2012) observe that only news categorized as highly relevant has a significant impact on market prices, hence news that is not classified as highly relevant is removed from the sample 6 . The sentiment of news items which arrive during each trading day are aggregated into a daily sentiment measure. Two measures are examined; the first is a simple sum of the sentiment scores (News_Sum) so that if the number of positive news events on a given day is greater (lower) than the number of negative events the day is assigned positive (negative) sentiment. For the second measure, following Dzielinski (2011), the sentiment of each news item is multiplied with its probability to compute a weighted average of the prevailing sentiment for that day (Eq.1).

$$
\text { News_Ave }=\frac{\sum 1 \cdot \text { prob }_{\text {positive }}+\sum(-1) \cdot \text { prob }_{\text {negative }}}{n_{\text {positive }}+n_{\text {neutral }}+n_{\text {negative }}} \in[-1,1]
$$

\footnotetext{
${ }^{6}$ The original sample of 98,096 news releases is reduced to 63,486 items.
} 
Although neutral news items do not enter the sentiment calculation in the numerator (owing to their sentiment of 0 ) the number shows up in the denominator pushing the measure downward, so that a day with many neutral news items would still be classified as neutral. This procedure is repeated for each trading day to obtain a complete history of news days and their respective sentiment classification.

\subsection{Data for Gold Derivatives Markets}

The empirical analysis in this paper considers the gold futures market $^{7}(\mathrm{GC})$. The most actively traded gold futures are those traded on COMEX (owned by Chicago Mercantile Exchange since August 2008), where the contract size is 100 troy ounces and the minimum price fluctuation is $\$ 0.10$ per troy ounce. For the period $2^{\text {nd }}$ January $2003-31^{\text {st }}$ October 2012, a continuous series of returns is created for using the settlement prices obtained from Thomson Reuters Tick History (TRTH) provided by SIRCA. The return is measured as the log of the percentage change in daily settlement prices; with the nearest-to-maturity contract used and switching to the second-nearest contract when the liquidity (measured by daily volume) becomes greater. Figure 1 depicts the evolution of the price of gold futures over the 10-year sample period, along with the S\&P500 Index for comparative purposes.

\section{$<$ Insert Figure 1>}

To allow for the investigation of the impact of market positioning, trader position data is taken from the CFTC's weekly COT reports. The key feature of this dataset is that it provides a decomposition of positions held by categorized on the basis of whether a trader holds a reportable commercial or non-commercial position as defined by the CFTC. Traders taking commercial positions to hedge a specific risk are regarded as hedgers, and those who take non-commercial positions for reasons other than hedging are viewed as speculators. Since commercial entities in the gold market are generally long the physical asset they are naturally short in the future market. In order to reflect the size of the trader positioning in terms of market size and liquidity, the nominal position for each trader type indicated in the COT report is divided by a rolling 1-year average of aggregate daily volume.

\footnotetext{
${ }^{7}$ Reuters symbol GC.
} 


\subsection{Macroeconomic Factors}

In order to investigate the influence of the business cycle and economic conditions on the reaction of gold derivative to news articles two types of measures are used. Firstly, the dates of recession $^{8}$ as defined by the National Bureau of Economic Research (NBER) are utilized to create a recession dummy variable $(R e c t)$; equal to 1 if the allotted trading day occurs during the recession and 0 otherwise. The second set of macroeconomic factors are derived from Bessembinder and Chan (1992) who demonstrate that the T-bill yield, default premium, and equity dividend yield are priced risk factors in futures markets. Therefore, data is collected from Datastream for the 3-month T-bill yield, Moody's BAA-rated long-term corporate bond yield, AAA-rated corporate bond yield, and S\&P 500 index dividend yield over the sample period.

\section{$<$ Insert Table 1>}

Table 1 presents summary statistics for the data utilised in this study. Panel A demonstrates that daily returns from gold futures were generally positive during the sample period, with no evidence of return predictability. There is some disagreement in the two measures of news sentiment, with the News_Sum measure negative on average and the News_Ave measure positive on average; not that both have large standard deviations relative to mean and significant partial autocorrelations. In-line with rapidly declining equity markets, and (still) expansionary monetary policy following the onset of the GFC, changes in the dividend yield are generally positive while interest rates are generally falling. Consistent with hedgers (gold producers) been long the underlying asset, they are short futures on average; in contrast, speculators are generally long.

Panel B disaggregates the sample period into that occurring prior to the Global Financial Crisis related recession of October 2007 - June 2009, the crisis period, and the post-crisis period. Gold futures returns are positive in all sub-periods, with the highest return occurring post-crisis and the greatest standard deviation of returns arising during the crisis period. Newswire stories are more frequent during the crisis period. Unsurprisingly news sentiment tended to be positive during the equity/property bull market prior to the crisis, and extremely negative during the crisis. News sentiment has remained negative post-crisis, this is likely to be at least partly due to the ensuing sovereign debt crisis in Europe.

8 The NBER defined recession in this sample period is that of Q4 2007 - Q2 2009, a period that also coincides with the global financial crisis. 


\section{Relationship between gold futures returns and news sentiment}

\subsection{Returns and news sentiment}

In this section I investigate the relationship between the returns on gold futures and measures of news sentiment. More specifically, I aim to ascertain the relationship between daily futures market returns and aggregated measures of news sentiment. It is important to note that in utilising contemporaneous specifications I do not wish to imply causality, but instead seek to examine the reliability of statistical relations. In order to examine this relationship I utilise a regression specification of the form:

$$
R_{t}=\beta_{0}+\sum_{t=-5}^{t} \beta_{1} N e w s_{t}+\beta_{2} X_{t}+\varepsilon_{t}
$$

Where $R_{t}$ is the return in the gold futures market during period $t, N e w s t$ is the sentiment of the highly relevant newswire items released during period $t, X_{t}$ is a vector of control variables including lagged returns and a dummy variable for the day of the week, and $\varepsilon_{t}$ is the error term.

$<$ Insert Table 2>

The results for this baseline model are reported in Table 2. The intercept is not significantly different from zero, suggesting that returns will not change in the absence of news. There is a positive and highly significant contemporaneous relationship between news sentiment and returns such that an increase (decrease) in news sentiment results in higher (lower) returns in the gold futures market. The negative and significant coefficient for lagged news is suggestive of a possible initial overreaction to news events which is reversed somewhat in subsequent periods; the magnitude of the lagged news sentiment coefficients is much smaller than that of contemporaneous news and gradually fall indicating that it may take several days to correct for the initial overreaction. Whilst there is no day of the week effect evident, there is significant evidence of negative autocorrelation in returns that is supportive of the idea of initial overreaction.

Having identified that gold futures react to highly relevant news, the news sentiment variable is next disaggregated into positive and negative components and regressed against futures returns. The results reported in Table 3 find a significant contemporaneous relationship for both negative and positive news sentiment with gold returns. There is clear evidence to support 
Hypothesis 1 such that the reaction to negative news is almost double that to positive news; this is also consistent with the assertion that gold may act as a safe haven in the presence of negative market news. Again there is significant negative autocorrelation of returns.

$<$ Insert Table 3>

\subsection{Effect of news sentiment and the business cycle}

This section seeks to investigate whether there is evidence to support Hypothesis 2 such that the business cycle, and in particular the presence of recession, has an impact on the way that gold futures prices respond to news; the extant literature suggests that the reaction to news should be greater during a recession. I first investigate whether the business cycle influences futures returns using regression specifications of the form:

$$
R_{t}=\beta_{0}+\sum \beta_{1} N e w s_{t}+\beta_{2} M_{t}+\beta_{3} X_{t}+\varepsilon_{t}
$$

Where Newst is the sentiment of the highly relevant newswire items released during period t, $M_{t}$ is a vector of macroeconomic variables indicative of the stage of the business cycle, $X_{t}$ is a vector of control variables including lagged returns and a dummy variable for the day of the week, and $\varepsilon_{t}$ is the error term. The first two columns of Table 4 utilize the macroeconomic variables suggested by Bessembinder and Chan (1992) as factors in futures pricing; that is changes in interest rates as determined by 3-month treasury bills, changes in the credit spread, and changes in the dividend yield of the S\&P 500. The already identified significant relationship between gold returns and news sentiment remains. More importantly, since gold is an asset that does not generate any income, it is intuitive to find that returns in the gold market fall (rise) as the opportunity cost for investors' increases (declines) with interest rates rises (falls). Additionally, consistent with the idea that gold is a hedge in times of falling equity markets, there is also a negative relationship with dividend yields. However, it is not necessarily the case that interest rates, credit spreads, and dividend yields move in a consistent direction during the recession phase of a business cycle. I therefore introduce a dummy variable that explicitly accounts for whether the economy is in recession during the period. The final two columns of Table 4 report provide additional evidence as to the safe haven nature of gold since returns increase during recession (noted by the significantly positive coefficient for the recession dummy). 
$<$ Insert Table 4>

Since it is apparent that the business cycle has an impact on gold futures returns, it is necessary to test whether the business cycle influences the relationship between news sentiment and the futures market. Confirmation of Hypothesis 2 is sought using a regression specification of the form:

$$
R_{t}=\beta_{0}+\beta_{1} \operatorname{News}_{t}+\beta_{2} \operatorname{Rec}_{t}+\beta_{3} \mathrm{News}_{t} \cdot \operatorname{Rec}_{t}+\beta_{4} X_{t}+\varepsilon_{t}
$$

Where Newst is the sentiment of the highly relevant newswire items released during period $\mathrm{t}, \operatorname{Rect}$ is a dummy variable indicating whether the economy is in recession (1) or not (0), $N e w S_{t} \cdot \operatorname{Rec}_{t}$ is an interaction term between news sentiment and recession, $X_{t}$ is a vector of control variables including lagged returns and a dummy variable for the day of the week, and $\varepsilon_{t}$ is the error term.

The first two columns of Table 5 present the results for a specification using the two aggregated news sentiment measures, while the last two columns present results when news sentiment is disaggregated into positive and negative factors. Considering the aggregated news results first; the positive relationship between news sentiment and returns persists, as does the higher returns exhibited during the crisis-related recession. Importantly, the interaction term with news sentiment and recession indicates that news has an additional impact, over and above that witnessed during normal business conditions, throughout the recession period. Turning to the last two columns, and the results occurring when news is disaggregated, the asymmetric impact of negative news on returns is again evident along with the significant impact of recession. Most salient are the coefficients for the variables of interaction between news and recession; notably it appears that negative news does not have any significant effect on returns during recession while positive news has a highly significant and positive impact on returns. Such results are consistent with the notion that market participants may be under-invested during recession in order to preserve capital, and thus when positive news does arrive they are able to add to inventory driving the price (and thus returns) higher in the process. The results also provide evidence in support of Hypothesis 2 and the extant literature (notably Dzielinski (2011) and Garcia (2013)).

$<$ Insert Table 5> 
After considering the impact of the business cycle on the relationship between news sentiment and gold returns, it may also be of interest to determine whether there is an economically intuitive relationship between the business cycle and news sentiment, and whether this may explain the greater reaction to positive news during recession. Table 6 reports results for the regression of economic variables on news sentiment. Credit spreads and dividend yields are likely to increase during periods of recession as businesses face tougher credit environments and stock prices fall, hence the significant and negative coefficients in the first two columns support the notion that news sentiment is more negative during challenging economic conditions. The last two columns reinforce this finding with news sentiment falling during periods designated as recessionary. Such results may provide at least a partial explanation as to why the impact of positive news is higher than that of negative news during recession.

$<$ Insert Table 6>

In summary, the evidence presented in this section is broadly supportive of the first two hypotheses. Firstly, returns in the gold futures market have a significant relationship with news sentiment and this relationship is asymmetric such that negative news has a greater impact on returns than negative news. Secondly, the business cycle influences the way in which news sentiment impacts gold returns. The impact of news is greatest during recession, and during such periods positive news actually has the greater effect; this may be at least partly explained by the finding that news sentiment is generally more negative during recessionary periods, and so positive news is less expected.

\section{The influence of market positioning}

\subsection{Market positioning and gold returns}

In seeking to determine whether market positioning has an impact on the relationship between news sentiment and returns in gold futures interaction variables are introduced into the regression specification as follows:

$$
R_{t}=\beta_{0}+\beta_{1} \text { News }_{t}+\beta_{2} \text { Spec }_{t}+\beta_{3} \text { Hedge }_{t}+\beta_{4} \text { News }_{t} \cdot \text { Spec }_{t}+\beta_{5} \text { News }_{t} \cdot \text { Hedge }_{t}+\beta_{6} X_{t}+\varepsilon_{t}
$$

Where $R_{t}$ is the return in the gold futures market during period $t, N e w s_{t}$ is the aggregate news sentiment measure during period $t, S_{p e c t}$ and Hedget reflect the net position of speculators 
and hedgers reported in the COT dataset and normalized by the 1-yr rolling average of daily trading volume at the start of period $t, X_{t}$ is a vector of control variables, and $\varepsilon t$ is the error term.

$<$ Insert Table 7>

The results are presented in Table 7. As in the previous specifications, there is a positive contemporaneous relationship between news sentiment and market returns such that positive (negative) news results in an increase (decrease) in returns. Columns 1 and 2 also demonstrate a positive relationship between the net positioning of both trader types and returns, so as traders enter long (short) positions the market returns tend to increase (decrease). Columns 3 and 4 confirm the relationships present in the first two columns and also introduce interaction terms between news sentiment and trader positioning; significant and positive relationships indicating that the market response to news sentiment increases with the size of market positioning. Columns 5 and 6 disaggregate the news sentiment into positive and negative components. Additional evidence of an asymmetric response to news emerges. Firstly, the coefficient for negative news is significant and several times larger than that for positive news. Secondly, the interaction terms for negative news and positioning are highly significant, while the equivalent terms for positive news are insignificant. Consistent with Hypothesis 3, the significance of the interaction terms does suggest that market positioning has an impact on the relationship between news and market returns. In particular, note that the interaction of negative news with speculator positioning is negative, this indicates that market returns are lower if negative news is released and speculators are long, consistent with the inventory adjustment model. Conversely, market returns are higher if there is negative news and hedgers are long (or at least less short).

\subsection{Does extreme market positioning affect the relationship between news sentiment and market returns?}

The evidence in the previous section suggests that market positioning has a statistically significant influence on the gold futures market response to news sentiment. However, one question that is not answered is whether extreme positioning (lowest or highest decile) is important. To examine this issue I introduce a set of dummy variables $\{S L, S S, H L, H S\}$ which take a value of 1 if the COT data indicates the positions of speculators $(S)$ or hedgers $(H)$ are in the highest decile (Long) or the lowest decile (Short) and 0 otherwise. 
The results reported in columns 1 and 2 of Table 8 once more demonstrate the asymmetric effect of news sentiment such that the response to negative news is greater than that for positive news. More importantly, there is evidence that market returns in the next period are significantly lower when speculators are extremely short (in reality this means when they are least long), and significantly higher when hedgers are extremely long (or least short), i.e. market returns in the next period are largest when traders have least capital invested in the market, consistent with the notion that when traders are able to add to their inventory position following news releases they push the market further faster. Columns 3 and 4 introduce a series of interaction terms between trader positioning dummies and news sentiment. Trader positioning appears to have a significant impact on the market response to news sentiment only when traders are positioned contrary to their normal trading behaviour, i.e. when speculators are extremely short (or least long) and when hedgers are extremely long (least short). Of particular interest is the statistically significant and negative coefficient for negative news when hedgers are extremely long. This result is consistent with hedging pressure to the extent that negative news will also impact the underlying asset (gold produced by the hedgers) so the hedgers will seek to increase their hedge (by selling more futures) and so pushing returns even lower than would be suggested by the initial sentiment of the news message.

\subsection{Do certain trader types have the ability to forecast news?}

It is of interest to investors considering placing capital in the gold market as to whether they can glean information as to the likely direction of the market given the publicly available COT position data. As such, investors are seeking to determine whether certain trader types have any ability in forecasting news events and hence prospective short-term returns. Table 9 presents results for a set of regression equations of the positioning of speculators and hedgers against news sentiment in the next period. Considering the overall positioning of traders first (columns 1,2,7,8) it is apparent that as the positioning of speculators (hedgers) get longer the news sentiment tends to become more positive (negative). The results in the remaining columns disaggregate the position data using dummy variables to indicate whether the speculators and hedgers are extremely long or short (highest and lowest decile of positions). Evidence suggests that when speculators are shortest (or least long) the news sentiment in the next period is negative, whilst when they are longest the news sentiment in the next period is more positive; the opposite appears to be true for hedgers who tend to be long prior to negative news and short prior to 
positive news. Hence, it would appear that speculators generally do have some ability in forecasting news sentiment, and potentially generate profits through doing so. The inability of hedgers to forecast news may partly explain why the reaction to negative news events when they are least hedged (most long / least short) is so significant.

\section{$<$ Table 9>}

In summary, there appears to be evidence in support of Hypothesis 3 such that the inventory position of traders influences the relationship between news sentiment and returns in the gold futures market. The effect of market positioning on this relationship is most significant when traders are holding positions contrary to their natural position (i.e. when speculators are short and / or when hedgers are long) and so the significant reaction is consistent with models of inventory adjustment and hedging pressure. At least part of this relationship may be explained by the ability of trader types to forecast news sentiment.

\section{Conclusion}

Modern computing technology, and recent advancement in software development, allows the modern researcher to overcome the assertion of Mindell (1961) that news is too ambiguous for quantitative analysis. This article utilises this technology to examine the relationship between the assessed sentiment of newswire messages and returns in the gold futures market. Building on evidence provided in the extant literature, three hypotheses are developed and tested in an attempt to comprehend the influence of the business cycle and market positioning on this news sentiment / return relationship.

An ordinary least square regression provides evidence of a significant contemporaneous relationship between news and returns. Disaggregating the news wire messages into those with positive sentiment and negative sentiment provides compelling evidence in support of Hypothesis 1 , such that there is an asymmetric response to news with negative news invoking a greater response than positive news. This result is consistent with the extant literature noted in the equity markets by Tetlock (2007), Groß-Klußmann (2011), Leinweber and Sisk (2011) and Smales (2012).

Augmenting the baseline model with macroeconomic factors and a recession indicator allows for consideration of the influence of the business cycle on the news sentiment / return relationship. Consistent with Hypothesis 2, and the work of Dzielinski (2011) and Garcia (2013), 
there is evidence to suggest that the impact of news is greatest during recessionary periods. It transpires that the asymmetry effect is reversed during recessionary periods with the impact positive news been greater than that for negative news; a result that may be partly explained by the finding that news sentiment is generally more negative during recession and so positive news is less expected by market participants.

COT data allows for an exploration as to how the news processing relationship in the gold futures market is affected by market positioning. The results indicate that speculators have some ability in forecasting news sentiment while hedgers are generally contrary indicators. Consistent with models of inventory control and hedging pressure there is evidence to suggest that market positioning has a significant impact on the relationship between news sentiment and market returns (Hypothesis 3) with the effect greatest when speculators are holding short positions and / or hedgers are holding long positions (contrary to their natural position). At least part of this relationship may be explained by the inability of hedgers to forecast negative news events when least hedged.

The results have implications for academics and market practitioners seeking to understand the relationship between news sentiment and market movements, together with the validity of the existing news analytics software. The results may also be of interest to investors who are considering the placement of assets into the gold market, particularly in terms of understanding how market positioning may influence or predict future returns, and how returns may be impacted under changing macroeconomic environments. If news sentiment data could be computed for a longer time period, it would be of interest to consider whether the results concerning the business cycle are applicable to a greater range of recessionary periods (as in Garcia (2013)) or just the recent GFC related recession of 2007 - 2009. Additionally, this work may be extended to other futures markets and it may be interesting to test the implementation of simple trading strategies based on the reported results. 


\section{References}

Amihud, Y., and H. Mendelson, 1980, Dealership market: Market making with inventory, Journal of Financial Economics, 8, 31-53

Antweiler, W., and M.Z. Frank, 2004, Is all that talk just noise? The information content of internet stock message boards, Journal of Finance, 59, 1259-1294

Bagehot, W., 1971, The only game in town, Financial Analysts Journal, 27 (2), 12-14

Baur, D.G., and B.M. Lucey, 2010, Is gold a hedge or a safe haven? An analysis of stocks, bonds and gold, The Financial Review, 45, 217-229

Baur, D.G., and T.K. McDermott, 2010, Is gold a safe haven? International evidence, Journal of Banking \& Finance, 34, 1886-1898

Bessembinder, H., 1992, Systematic risk, hedging pressure, and risk premiums in futures markets, Review of Financial Studies, 5, 637-667

Bessembinder, H., and K. Chan, 1992, Time-varying risk premia and forecastable returns in futures markets, Journal of Financial Economics, 32, 169-193

Black, F., 1986, Noise, Journal of Finance, 41, 529-543

Boyd, J.H., J. Hu, and R. Jagannathan, 2005, The stock market's reaction to unemployment news: Why bad news is usually good for stocks, Journal of Finance, 60, 649-672

Brooks, R.M., A. Patel, and T. Su, 2003, How the equity market responds to unanticipated events, Journal of Business, 76, 109-133

Brown, G.W., and M.T. Cliff, 2005, Investor sentiment and asset valuation, Journal of Business, 78, 405-440

Capie. F., T.C. Mills, and G. Wood, 2005, Gold as a hedge against the dollar, Journal of International Financial Markets, Institutions and Money, 15 (4), 343-352

Chan, W.S., 2003, Stock price reaction to news and no-news: drift and reversal after headlines, Journal of Financial Economics, 70, 223-260

Chang, E.C., 1985, Returns to speculators and the theory of normal backwardation, Journal of Finance, 40, 193-208

Cutler, D.M., J.M. Poterba, and L.H. Summers, 1989, What moves stock prices? Journal of Portfolio Management, 15, 4-12

De Bondt, W.F.M., and R. Thaler, Does the stock market overreact? Journal of Finance, 40, 793805 
Draper, P., D. Hillier, and R. Faff, 2006, Do precious metals shine? An investment perspective, Financial Analysts Journal, 62 (2), 98-106

Dzielinski, M., 2011, News sensitivity and the cross-section of stock returns, NCCR Finrisk working paper no. 719

Dzielinski, M., 2012, Which news resolves asymmetric information? NCCR Finrisk working paper no. 800

Ederington, L.H., and J.H. Lee, 1995, The short-run dynamics of the price adjustment to new information, Journal of Financial and Quantitative Analysis, 30, 117-134

Engelberg, J., 2008, Costly information processing: Evidence from earnings announcements, Working Paper

Engelberg, J., A.V. Reed, and M.C. Ringgenberg, 2012, How are shorts informed? Short sellers, news, and information processing, Journal of Financial Economics, 105, 260-278

Erb, C.B, and C.R. Harvey, 2013, The golden dilemma, Financial Analysts Journal, 69 (4), 10-42

Garcia, D., 2013, Sentiment during recessions, Journal of Finance, 68, 1267-1300

Garman, M., 1976, Market microstructure, Journal of Financial Economics, 3, 257-275

Groß-Klußmann, A., and N. Hautsch, 2011, When machines read the news: Using automated text analytics to quantify high frequency news-implied market reactions, Journal of Empirical Finance, 18, 321-340

Hamilton, J.D., and G. Lin, 1996, Stock market volatility and the business cycle, Journal of Applied Econometrics, 11, 573-593

Jensen, G., J. Mercer, and R. Johnson, 1996, Business conditions, monetary policy, and expected security returns, Journal of Financial Economics, 40, 213-237

Kahneman, D., and A. Tversky, 1979, Prospect theory: An analysis of decision under risk, Econometrica, 47, 263-291

Kalev, P.S., W-M. Liu, P.K. Pham, and E. Jarnecic, 2004, Public information arrival and volatility of intraday stock returns, Journal of Banking \& Finance, 28, 1441-1467

Kandel, S., and R.F. Stambaugh, 1990, Expectations and volatility of consumption and asset returns, Review of Financial Studies, 3, 207-232

Leinweber, D., and J. Sisk, 2011, Event driven trading and the 'new news', Journal of Portfolio Management, 38, 110-124

Madhavan, A., 2000, Market microstructure: A Survey, Journal of Financial Markets, 3, 205-258 
McCown, J.R., and J.R. Zimmerman, 2006, Is gold a zero-beta asset? Analysis of the investment potential of precious metals, Working Paper

McQueen, G., and V.V. Roley, 1993, Stock prices, news, and business conditions, Review of Financial Studies, 6, 683-707

Mindell, J., 1961, How news affects market trends, Financial Analysts Journal, 17 (1), 31-34

Riordan, R., A. Storkenmaier, M. Wagener, and S.S. Zhang, 2013, Public information arrival: Price discovery and liquidity in electronic order markets, Journal of Banking \& Finance, 37, 11481159

Roll, R.W., 1988, R-squared, Journal of Finance, 43, 541-566

Sherman, E.J., 1982, Gold: A conservative, prudent diversifier, Journal of Portfolio Management, 8 (3) 21-27

Sinha, N.R., 2011, Under-reaction to news in the US stock market, Working Paper

Smales, L.A., 2012, Non-scheduled news arrival and high-frequency stock market dynamics: Evidence from the Australian stock exchange, Working Paper

Stoll, H., 1978, The supply of dealer services in securities markets, Journal of Finance, 33, 11331151

Tetlock, P.C., 2007, Giving content to investor sentiment: The role of media in the stock market, Journal of Finance, 62, 1139-1168

Tetlock, P.C., M. Saar-Tsechansky, and S. Macskassy, 2008, More than words: Quantifying language to measure firms' fundamentals, Journal of Finance, 63, 1437-1467

Veronesi, P., 1999, Stock market overreaction to bad news in good times: A rational expectations equilibrium model, Review of Financial Studies, 12, 975-1007

Wang, C., 2001, Investor sentiment and return predictability in agricultural futures markets, Journal of Futures Markets, 21, 929-952

Wang, C., 2003a, The behaviour and performance of major types of futures traders, Journal of Futures Markets, 23, 1-31

Wang, C., 2003b, Investor sentiment, market timing, and futures returns, Applied Financial Economics, 13, 891-898

Wang, C., 2004, Futures trading activity and predictable foreign exchange market movements, Journal of Banking \& Finance, 28, 1023-1041 


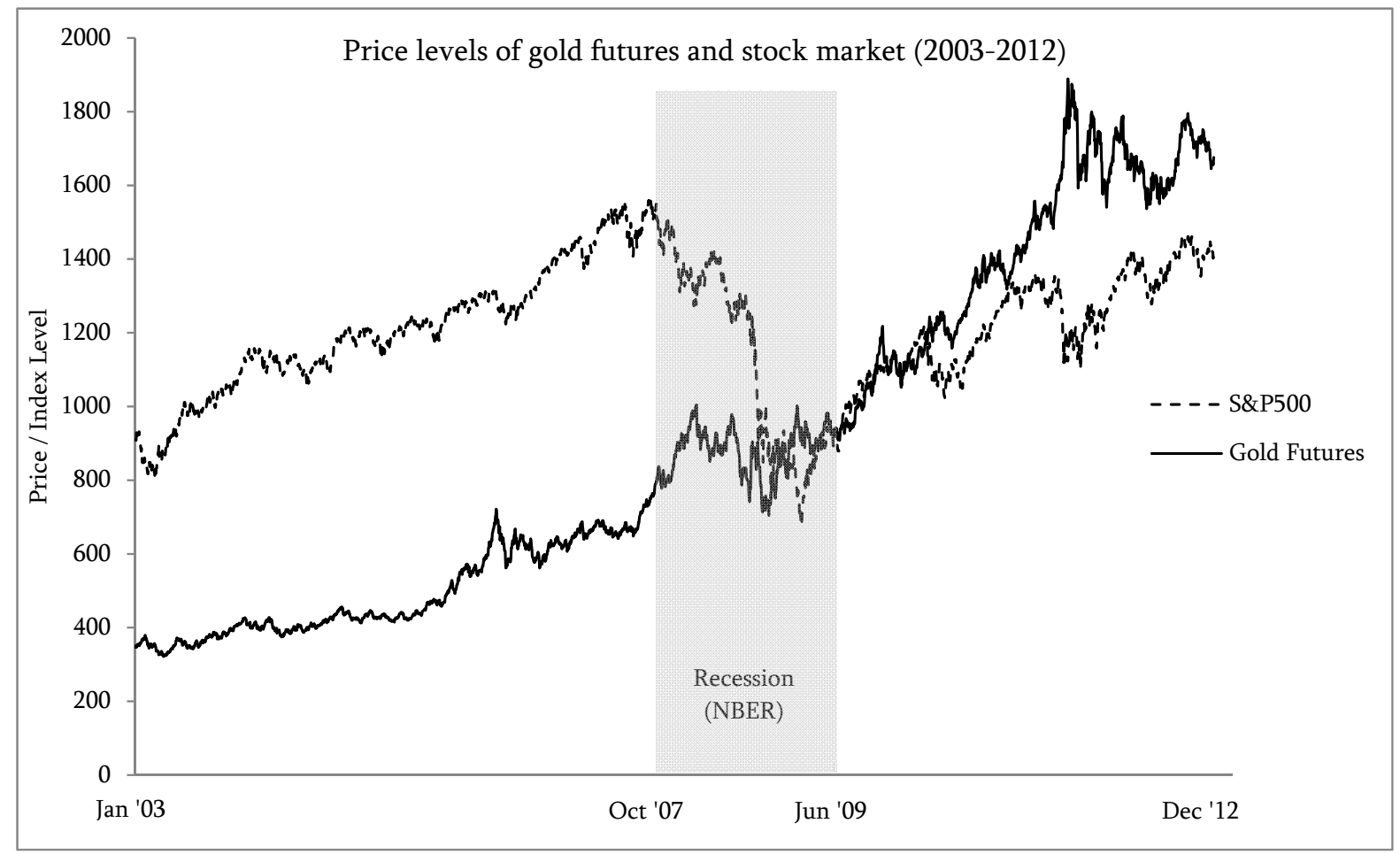

Figure 1

Evolution of the price levels of gold futures and the U.S. stock market over the period 2003 - 2012. 


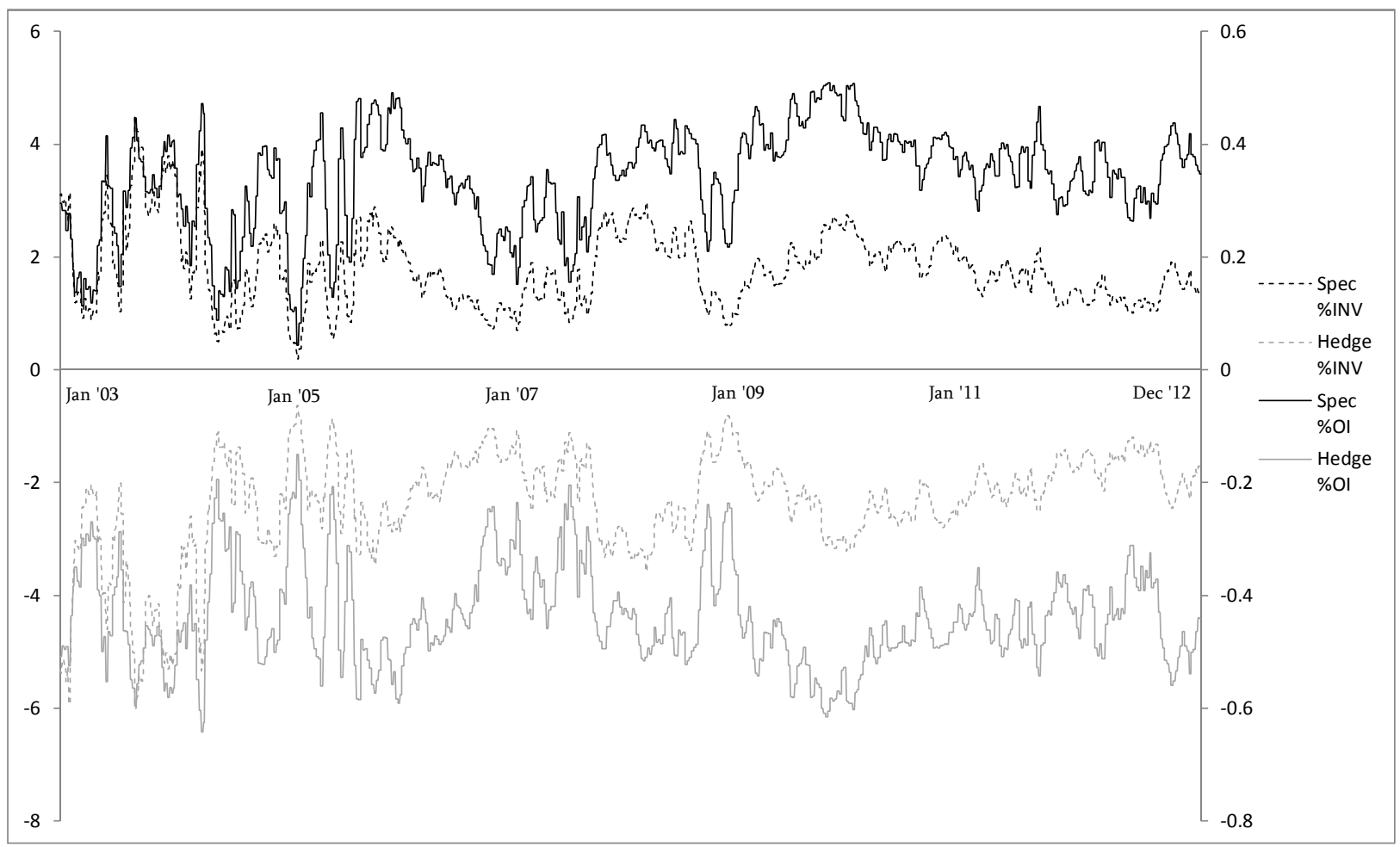

Figure 2

Speculator and Hedger Trader Positions as Proportion of Inventory (INV) and Open Interest (OI). 
Table 1

Summary Statistics

\begin{tabular}{|c|c|c|c|c|c|c|c|c|c|c|c|}
\hline \multirow[t]{2}{*}{ Panel $A$} & \multirow[b]{2}{*}{ Mean } & \multirow[b]{2}{*}{ SD } & \multirow[b]{2}{*}{ Skewness } & \multirow[b]{2}{*}{ Jarque-Bera } & \multicolumn{5}{|c|}{ Partial Autocorrelation at Lag: } & \multicolumn{2}{|l|}{ Unit Root Test } \\
\hline & & & & & 1 & 2 & 3 & 4 & 5 & Statistic & \\
\hline Futures Return (\%) $\left(R_{t}\right)$ & 0.065 & 1.257 & -0.288 & 1430.2 & 0.010 & -0.020 & -0.001 & 0.005 & 0.012 & -49.13 & * \\
\hline News_Ave & 0.008 & 0.103 & -0.202 & 19.3 & 0.335 & 0.087 & 0.087 & 0.055 & 0.044 & -9.83 & * \\
\hline Speculator Net Position / INV & 1.795 & 0.688 & 0.660 & 213.2 & 0.983 & -0.012 & -0.008 & -0.019 & -0.022 & -5.58 & * \\
\hline Speculator Net Position / OI & 0.339 & 0.091 & -0.629 & 162.6 & 0.983 & -0.009 & -0.009 & -0.015 & -0.030 & -6.08 & * \\
\hline Hedger Net Position / INV & -2.361 & 0.930 & -1.300 & 1204.0 & 0.987 & -0.013 & -0.007 & -0.013 & -0.026 & -5.32 & * \\
\hline Hedger Net Position / OI & -0.439 & 0.088 & 0.582 & 139.8 & 0.979 & -0.011 & -0.011 & -0.016 & -0.017 & -6.30 & * \\
\hline$\% \Delta$ Yield (3m T-Bill) & -0.032 & 18.260 & -0.972 & 5468 & -0.184 & -0.209 & -0.125 & -0.014 & 0.012 & -39.86 & * \\
\hline$\% \Delta$ Credit Spread & -0.006 & 1.736 & 0.265 & 1367 & -0.027 & 0.045 & 0.069 & 0.071 & 0.069 & -18.44 & * \\
\hline$\% \Delta$ Dividend Yield & 0.052 & 2.482 & 0.287 & 10.78 & -0.126 & -0.144 & -0.167 & -0.079 & -0.066 & -10.64 & * \\
\hline
\end{tabular}

\begin{tabular}{lcccccccc}
\hline Panel B & \multicolumn{3}{c}{ Variation of news sentiment and trader position during the business cycle } \\
& \multicolumn{2}{c}{ Overall } & \multicolumn{2}{c}{ Pre-recession } & \multicolumn{3}{c}{ Recession } & Post-recession \\
& Mean & SD & Mean & SD & Mean & SD & Mean & SD \\
\hline$R_{t}$ & 0.065 & 1.257 & 0.064 & 1.102 & 0.050 & 1.767 & 0.074 & 1.135 \\
News Frequency & 38.32 & 13.08 & 37.02 & 8.61 & 44.90 & 16.55 & 36.72 & 15.08 \\
News_Ave & 0.008 & 0.103 & 0.027 & 0.096 & -0.028 & 0.104 & 0.000 & 0.106 \\
Speculator Net Position /INV & 1.795 & 0.688 & 1.753 & 0.840 & 1.947 & 0.582 & 1.775 & 0.445 \\
Hedger Net Position /INV & -2.361 & 0.930 & -2.520 & 1.171 & -2.309 & 0.722 & -2.163 & 0.502 \\
\hline
\end{tabular}

This table presents summary data for the variables utilised in this study, using daily observations for the period 03 Jan 2003 - 13 October 2012 . News_Ave is a measure of aggregate news sentiment for highly relevant newswire messages defined in Eq.1. Speculator and Hedger net positions are taken from CFTC COT dataset, and normalised by levels of inventory (INV) and open interest (OI). Unit root tests are conducted using Augmented Dickey Fuller with trend and intercept. ${ }^{*}$ indicates rejection of the null of a unit root. Panel B disaggregates the sample of news sentiment and trader position measures into different stages of the business cycle where recession is defined by NBER as the period Q4 2007 - Q2 2009. 
Table 2

Relationship between news measures and gold futures returns

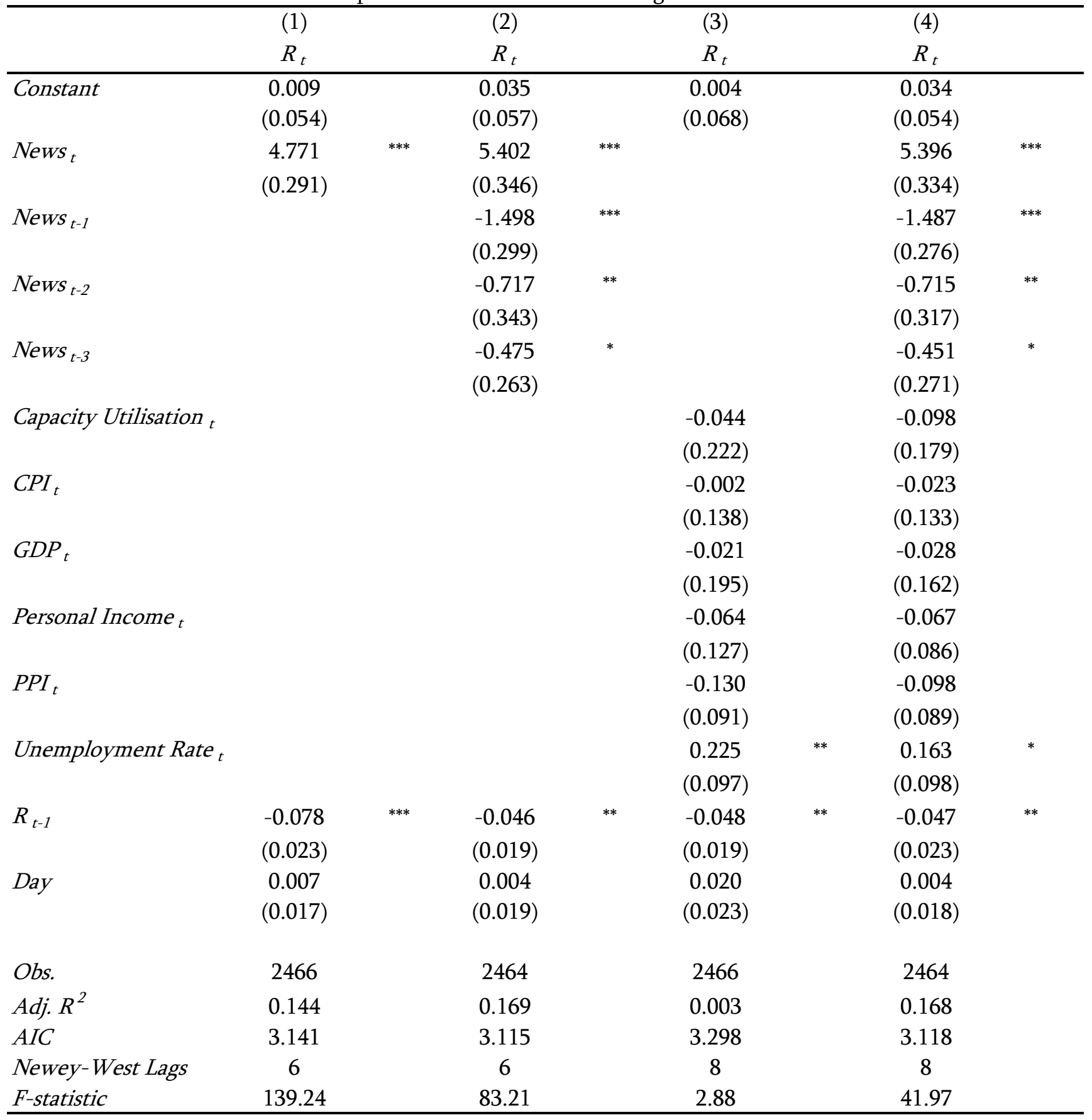

This table presents regression results from equation (2) with returns in the gold futures market during period $t\left(R_{t}\right)$ as the dependent variable. The News variable is News_Ave (News_Sum not reported here produces qualitatively similar results). Surprise components of macroeconomic news variables are included in columns 3 \& 4. Newey-West standard errors are shown in parantheses, where the appropriate number of lags in each case is determined using Akaike Information Criterion (AIC). ${ }^{* * *},{ }^{* *}$, and ${ }^{*}$ denote significance at the $1 \%, 5 \%$ and $10 \%$ levels respectively. 
Table 3

Disaggregating the news effect

\begin{tabular}{|c|c|c|c|c|c|c|}
\hline \multirow{3}{*}{ Constant } & \multirow{2}{*}{$\begin{array}{l}(1) \\
R_{t}\end{array}$} & & \multirow{2}{*}{$\begin{array}{l}(2) \\
R_{t} \\
\end{array}$} & \multicolumn{3}{|c|}{ (3) } \\
\hline & & & & & $R_{t}$ & \\
\hline & $\begin{array}{c}0.122 \\
(0.069)\end{array}$ & & $\begin{array}{c}0.011 \\
(0.058)\end{array}$ & & $\begin{array}{c}0.131 \\
(0.063)\end{array}$ & \\
\hline$\left|-N e w s_{t}\right|$ & $\begin{array}{l}-6.098 \\
(0.695)\end{array}$ & *** & & & $\begin{array}{l}-6.130 \\
(0.610)\end{array}$ & *** \\
\hline+ News $_{t}$ & $\begin{array}{c}3.456 \\
(0.437)\end{array}$ & $* * *$ & & & $\begin{array}{c}3.412 \\
(0.422)\end{array}$ & *** \\
\hline |-Capacity Utilisation ${ }_{t} /$ & & & $\begin{array}{c}0.030 \\
(0.279)\end{array}$ & & $\begin{array}{c}0.105 \\
(0.236)\end{array}$ & \\
\hline+ Capacity Utilisation $_{t}$ & & & $\begin{array}{l}-0.108 \\
(0.209)\end{array}$ & & $\begin{array}{l}-0.129 \\
(0.184)\end{array}$ & \\
\hline$\left|-C P I_{t}\right|$ & & & $\begin{array}{c}0.142 \\
(0.121)\end{array}$ & & $\begin{array}{c}0.164 \\
(0.137)\end{array}$ & \\
\hline$+C P I_{t}$ & & & $\begin{array}{l}-0.143 \\
(0.082)\end{array}$ & $*$ & $\begin{array}{l}-0.190 \\
(0.217)\end{array}$ & ${ }^{*}$ \\
\hline$\left|-G D P_{t}\right|$ & & & $\begin{array}{c}0.323 \\
(0.161)\end{array}$ & ** & $\begin{array}{c}0.311 \\
(0.150)\end{array}$ & ** \\
\hline$+G D P_{t}$ & & & $\begin{array}{l}-0.390 \\
(0.292)\end{array}$ & & $\begin{array}{l}-0.346 \\
(0.283)\end{array}$ & \\
\hline /-Personal Income $t /$ & & & $\begin{array}{c}0.354 \\
(0.208)\end{array}$ & $*$ & $\begin{array}{c}0.149 \\
(0.212)\end{array}$ & \\
\hline+ Personal Income $_{t}$ & & & $\begin{array}{l}-0.001 \\
(0.141)\end{array}$ & & $\begin{array}{l}-0.023 \\
(0.129)\end{array}$ & \\
\hline$\left|-P P I_{t}\right|$ & & & $\begin{array}{c}0.181 \\
(0.115)\end{array}$ & & $\begin{array}{c}0.152 \\
(0.094)\end{array}$ & \\
\hline$+P P I_{t}$ & & & $\begin{array}{l}-0.098 \\
(0.128)\end{array}$ & & $\begin{array}{l}-0.112 \\
(0.125)\end{array}$ & \\
\hline |-Unemployment Rate ${ }_{t} /$ & & & $\begin{array}{l}-0.213 \\
(0.121)\end{array}$ & * & $\begin{array}{l}-0.182 \\
(0.121)\end{array}$ & \\
\hline$+{\text { Unemployment } \text { Rate }_{t}}$ & & & $\begin{array}{c}0.239 \\
(0.114)\end{array}$ & ** & $\begin{array}{c}0.283 \\
(0.115)\end{array}$ & ** \\
\hline$R_{t-1}$ & $\begin{array}{l}-0.079 \\
(0.019)\end{array}$ & *** & $\begin{array}{l}-0.090 \\
(0.023)\end{array}$ & *** & $\begin{array}{l}-0.080 \\
(0.022)\end{array}$ & *** \\
\hline Day & $\begin{array}{c}0.006 \\
(0.019)\end{array}$ & & $\begin{array}{c}0.017 \\
(0.019)\end{array}$ & & $\begin{array}{c}0.005 \\
(0.017)\end{array}$ & \\
\hline Obs. & 2466 & & 2466 & & 2466 & \\
\hline Adj. $R^{2}$ & 0.148 & & 0.005 & & 0.148 & \\
\hline AIC & 3.136 & & 3.301 & & 3.141 & \\
\hline Newey-West Lags & 12 & & 3 & & 3 & \\
\hline F-statistic & 107.94 & & 0.967 & & 27.77 & \\
\hline
\end{tabular}

This table presents regression results from equation (2) with returns in the gold futures market during period $t\left(R_{t}\right)$ as the dependent variable. The News variable (News_Ave) and macroeconomic variables are disaggregated into positive and negative components. Newey-West standard errors are shown in parantheses, where the appropriate number of lags in each case is determined using Akaike Information Criterion (AIC). ${ }^{* * *}$, ${ }^{* *}$, and ${ }^{*}$ denote significance at the $1 \%, 5 \%$ and $10 \%$ levels respectively. 
Table 4

Influence of net trader positions on the news sentiment / return relationship

\begin{tabular}{|c|c|c|c|c|c|c|c|c|c|c|c|c|}
\hline & $\begin{array}{l}(1) \\
R_{t}\end{array}$ & & $\begin{array}{l}(2) \\
R_{t}\end{array}$ & & $\begin{array}{l}(3) \\
R_{t}\end{array}$ & & $\begin{array}{l}(4) \\
R_{t}\end{array}$ & & $\begin{array}{l}(5) \\
R_{t}\end{array}$ & & $\begin{array}{l}(6) \\
R_{t}\end{array}$ & \\
\hline Constant & $\begin{array}{c}0.078 \\
(0.069)\end{array}$ & & $\begin{array}{c}0.059 \\
(0.071)\end{array}$ & & $\begin{array}{c}0.192 \\
(0.108)\end{array}$ & $*$ & $\begin{array}{c}0.334 \\
(0.099)\end{array}$ & *** & $\begin{array}{c}0.534 \\
(0.156)\end{array}$ & *** & $\begin{array}{c}0.555 \\
(0.249)\end{array}$ & ** \\
\hline $\mathrm{News}_{t}$ & $\begin{array}{c}4.873 \\
(0.354)\end{array}$ & $* * *$ & $\begin{array}{c}5.656 \\
(0.858)\end{array}$ & $* * *$ & & & $\begin{array}{c}6.391 \\
(1.056)\end{array}$ & *** & & & & \\
\hline $\mid-$ News $_{t} \mid$ & & & & & $\begin{array}{l}-6.600 \\
(1.876)\end{array}$ & $* * *$ & & & $\begin{array}{l}-8.186 \\
(2.395)\end{array}$ & $* * *$ & $\begin{array}{l}-8.681 \\
(3.401)\end{array}$ & ** \\
\hline+ News $_{t}$ & & & & & $\begin{array}{c}3.715 \\
(1.324)\end{array}$ & *** & & & $\begin{array}{c}3.651 \\
(1.687)\end{array}$ & ** & $\begin{array}{c}0.969 \\
(2.872)\end{array}$ & \\
\hline Speculator $_{\mathrm{t}}$ & $\begin{array}{c}0.268 \\
(0.102)\end{array}$ & $* * *$ & $\begin{array}{c}0.252 \\
(0.101)\end{array}$ & ** & $\begin{array}{c}0.529 \\
(0.155)\end{array}$ & $* * *$ & $\begin{array}{c}0.187 \\
(0.057)\end{array}$ & *** & $\begin{array}{c}0.121 \\
(0.049)\end{array}$ & ** & $\begin{array}{c}4.449 \\
(1.211)\end{array}$ & *** \\
\hline Hedger $_{\mathrm{t}}$ & $\begin{array}{c}0.223 \\
(0.079)\end{array}$ & *** & $\begin{array}{c}0.199 \\
(0.075)\end{array}$ & ** & $\begin{array}{c}0.427 \\
(0.117)\end{array}$ & ${ }^{* * *}$ & $\begin{array}{c}0.039 \\
(0.018)\end{array}$ & ** & $\begin{array}{c}0.028 \\
(0.017)\end{array}$ & & $\begin{array}{c}4.423 \\
(1.318)\end{array}$ & $* * *$ \\
\hline News $_{\mathrm{t}}{ }^{*}$ Speculator $_{t}$ & & & $\begin{array}{c}1.290 \\
(0.562)\end{array}$ & ** & & & $\begin{array}{c}1.526 \\
(0.607)\end{array}$ & ** & & & & \\
\hline News $_{t}{ }^{*}$ Hedger $_{t}$ & & & $\begin{array}{c}1.039 \\
(0.493)\end{array}$ & ** & & & $\begin{array}{c}1.356 \\
(0.464)\end{array}$ & *** & & & & \\
\hline $\mid-$ News $_{t} \mid{ }^{*}$ Speculator ${ }_{t}$ & & & & & $\begin{array}{l}-4.578 \\
(2.074)\end{array}$ & ** & & & $\begin{array}{l}-2.875 \\
(1.338)\end{array}$ & ** & $\begin{array}{l}-31.734 \\
(15.349)\end{array}$ & ** \\
\hline$+{ }^{N}{ }^{2} s_{\mathrm{t}}{ }^{*}$ Speculator $_{t}$ & & & & & $\begin{array}{l}-2.215 \\
(1.519)\end{array}$ & & & & $\begin{array}{c}1.151 \\
(0.919)\end{array}$ & & $\begin{array}{c}-16.412 \\
(13.675)\end{array}$ & \\
\hline$\left|-\mathrm{News}_{t}\right|{ }^{*} \mathrm{Hedger}_{t}$ & & & & & $\begin{array}{l}-3.764 \\
(1.515)\end{array}$ & ** & & & $\begin{array}{l}-2.329 \\
(1.070)\end{array}$ & ** & $\begin{array}{c}-30.614 \\
(18.541)\end{array}$ & $*$ \\
\hline+ News $_{t}{ }^{*}$ Hedger $_{t}$ & & & & & $\begin{array}{c}1.636 \\
(0.814)\end{array}$ & ** & & & $\begin{array}{c}0.747 \\
(0.299)\end{array}$ & $* *$ & $\begin{array}{l}18.578 \\
(8.950)\end{array}$ & ** \\
\hline$R_{t-1}$ & $\begin{array}{l}-0.081 \\
(0.019)\end{array}$ & $* * *$ & $\begin{array}{l}-0.081 \\
(0.023)\end{array}$ & *** & $\begin{array}{l}-0.082 \\
(0.019)\end{array}$ & *** & $\begin{array}{l}-0.084 \\
(0.022)\end{array}$ & *** & $\begin{array}{l}-0.085 \\
(0.023)\end{array}$ & *** & $\begin{array}{l}-0.083 \\
(0.019)\end{array}$ & *** \\
\hline Obs. & 2466 & & 2466 & & 2466 & & 2466 & & 2466 & & 2466 & \\
\hline Adj. $R^{2}$ & 0.147 & & 0.147 & & 0.152 & & 0.154 & & 0.158 & & 0.153 & \\
\hline AIC & 3.137 & & 3.138 & & 3.134 & & 3.130 & & 3.126 & & 3.132 & \\
\hline Newey-West Lags & 8 & & 9 & & 8 & & 4 & & 3 & & 8 & \\
\hline F-statistic & 107.42 & & 72.27 & & 50.06 & & 75.89 & & 52.41 & & 50.59 & \\
\hline
\end{tabular}

I his tabie presents regression results from equation (S) with returns in the gold futures market during period $t\left(K_{t}\right)$ as the dependent variable. I ne ivews variable is News_Ave (results using News_Sum are qualitatively similar). News is also disaggregated into positive $\left(+N e w s_{t}\right)$ and negative $\left(-N e w s_{t}\right)$ components. The net position of speculators $\left(\right.$ Speculator $\left._{t}\right)$ and hedgers $\left(\right.$ Hedger $\left._{t}\right)$ is normalized by dividing by inventory levels in columns 1,2,3 and by open interest in column 6. In column 4 and 5 the Speculator and Hedger positions are represented by outright long and outright short positions respectively (normalized by inventory). There is a series of interaction variables between news sentiment and trader position. Newey-West standard errors are shown in parantheses, where the appropriate number of lags in each case is determined using Akaike Information Criterion (AIC). ${ }^{* *},{ }^{* *}$, and ${ }^{*}$ denote significance at the $1 \%, 5 \%$ and $10 \%$ levels respectively. 
Table 5

Influence of extreme net trader positions on the news-return and news-volume relationship

\begin{tabular}{|c|c|c|c|c|c|c|c|c|c|c|c|c|}
\hline & $\begin{array}{l}(1) \\
R_{t}\end{array}$ & & $\begin{array}{l}(2) \\
R_{t}\end{array}$ & & $\begin{array}{l}(3) \\
R_{t}\end{array}$ & & $\begin{array}{c}(4) \\
\text { Volum }\end{array}$ & & $\begin{array}{c}(5) \\
\log \left(\text { Volume }_{t}\right)\end{array}$ & & $\begin{array}{c}(6) \\
\text { (Volum }\end{array}$ & \\
\hline Constant & $\begin{array}{c}0.126 \\
(0.038)\end{array}$ & *** & $\begin{array}{c}0.145 \\
(0.039)\end{array}$ & *** & $\begin{array}{c}0.144 \\
(0.046)\end{array}$ & *** & $\begin{array}{c}0.836 \\
(0.101)\end{array}$ & **** & $\begin{array}{c}0.773 \\
(0.101)\end{array}$ & **** & $\begin{array}{c}0.852 \\
(0.109)\end{array}$ & $* * *$ \\
\hline $\mid-$ News $_{t} \mid$ & $\begin{array}{l}-6.266 \\
(0.673)\end{array}$ & *** & $\begin{array}{l}-6.643 \\
(0.883)\end{array}$ & $* * *$ & $\begin{array}{l}-6.631 \\
(0.908)\end{array}$ & $* * *$ & $\begin{array}{c}1.738 \\
(0.496)\end{array}$ & $* * *$ & $\begin{array}{c}2.207 \\
(0.632)\end{array}$ & $* * *$ & $\begin{array}{c}1.676 \\
(0.691)\end{array}$ & ** \\
\hline+ News $_{t}$ & $\begin{array}{c}3.479 \\
(0.482)\end{array}$ & *** & $\begin{array}{c}3.351 \\
(0.616)\end{array}$ & $* * *$ & $\begin{array}{c}3.352 \\
(0.673)\end{array}$ & $* * *$ & $\begin{array}{c}0.550 \\
(0.486)\end{array}$ & & $\begin{array}{c}0.941 \\
(0.539)\end{array}$ & $*$ & $\begin{array}{c}0.378 \\
(0.581)\end{array}$ & \\
\hline$S L_{\mathrm{t}}$ & $\begin{array}{c}0.223 \\
(0.100)\end{array}$ & $* *$ & & & $\begin{array}{c}0.388 \\
(0.143)\end{array}$ & $* * *$ & $\begin{array}{c}0.134 \\
(0.061)\end{array}$ & ** & & & $\begin{array}{c}0.090 \\
(0.138)\end{array}$ & \\
\hline$S S_{\mathrm{t}}$ & $\begin{array}{l}-0.164 \\
(0.099)\end{array}$ & $*$ & & & $\begin{array}{l}-0.182 \\
(0.109)\end{array}$ & $*$ & $\begin{array}{l}-0.091 \\
(0.115)\end{array}$ & & & & $\begin{array}{l}-0.121 \\
(0.179)\end{array}$ & \\
\hline$H L_{\mathrm{t}}$ & $\begin{array}{c}0.253 \\
(0.119)\end{array}$ & ** & & & $\begin{array}{c}0.223 \\
(0.109)\end{array}$ & $* *$ & $\begin{array}{l}-0.066 \\
(0.114)\end{array}$ & & & & $\begin{array}{l}-0.082 \\
(0.175)\end{array}$ & \\
\hline$H S_{\mathrm{t}}$ & $\begin{array}{l}-0.208 \\
(0.093)\end{array}$ & ** & & & $\begin{array}{l}-0.414 \\
(0.141)\end{array}$ & $* * *$ & $\begin{array}{c}0.249 \\
(0.099)\end{array}$ & ** & & & $\begin{array}{l}-0.059 \\
(0.129)\end{array}$ & \\
\hline $\mid-N e w s_{t} /{ }^{*} S L_{t}$ & & & $\begin{array}{l}-2.550 \\
(1.258)\end{array}$ & $* *$ & $\begin{array}{l}-4.939 \\
(2.316)\end{array}$ & ** & & & $\begin{array}{c}1.991 \\
(1.003)\end{array}$ & ** & $\begin{array}{c}2.704 \\
(1.353)\end{array}$ & ** \\
\hline $\mid-N e w s_{t} /{ }^{*} S S_{t}$ & & & $\begin{array}{l}-1.860 \\
(1.427)\end{array}$ & & $\begin{array}{l}-0.431 \\
(1.634)\end{array}$ & & & & $\begin{array}{l}-0.993 \\
(1.486)\end{array}$ & & $\begin{array}{l}-0.144 \\
(1.814)\end{array}$ & \\
\hline$/-\mathrm{News}_{t} /{ }^{*} H L_{t}$ & & & $\begin{array}{c}2.692 \\
(1.699)\end{array}$ & & $\begin{array}{l}1.006 \\
(2.155)\end{array}$ & & & & $\begin{array}{l}-0.518 \\
(1.463)\end{array}$ & & $\begin{array}{l}-0.036 \\
(1.779)\end{array}$ & \\
\hline $\mid-$ News $_{t} /{ }^{*} H S_{t}$ & & & $\begin{array}{c}2.887 \\
(2.493)\end{array}$ & & $\begin{array}{c}6.498 \\
(2.841)\end{array}$ & $* *$ & & & $\begin{array}{l}-1.750 \\
(0.874)\end{array}$ & $* *$ & $\begin{array}{l}-1.278 \\
(0.518)\end{array}$ & ** \\
\hline$+{ }^{N}$ Newst ${ }^{*} S L t$ & & & $\begin{array}{l}-0.319 \\
(2.083)\end{array}$ & & $\begin{array}{l}-0.730 \\
(1.242)\end{array}$ & & & & $\begin{array}{c}2.121 \\
(1.216)\end{array}$ & $*$ & $\begin{array}{c}2.828 \\
(1.485)\end{array}$ & $*$ \\
\hline+ Newst $^{*}$ SSt & & & $\begin{array}{c}2.063 \\
(0.869)\end{array}$ & $* * *$ & $\begin{array}{c}2.226 \\
(0.867)\end{array}$ & ** & & & $\begin{array}{c}1.072 \\
(0.542)\end{array}$ & ** & $\begin{array}{c}0.899 \\
(0.422)\end{array}$ & ** \\
\hline+ Newst ${ }^{*} H L t$ & & & $\begin{array}{c}1.166 \\
(3.175)\end{array}$ & & $\begin{array}{l}-0.721 \\
(3.517)\end{array}$ & & & & $\begin{array}{c}0.050 \\
(1.747)\end{array}$ & & $\begin{array}{l}0.641 \\
(2.43)\end{array}$ & \\
\hline$+N e w s t^{*} H S t$ & & & $\begin{array}{l}2.130 \\
(0.796)\end{array}$ & $* * *$ & $\begin{array}{l}1.870 \\
(0.917)\end{array}$ & ** & & & $\begin{array}{c}3.265 \\
(1.229)\end{array}$ & $* * *$ & $\begin{array}{c}2.788 \\
(1.394)\end{array}$ & ** \\
\hline$R_{t-1}$ & $\begin{array}{l}-0.082 \\
(0.020)\end{array}$ & *** & $\begin{array}{l}-0.082 \\
(0.019)\end{array}$ & $* * *$ & $\begin{array}{l}-0.084 \\
(0.019)\end{array}$ & $* * *$ & & & & & & \\
\hline $\log \left(\right.$ Volume $\left._{t-1}\right)$ & & & & & & & $\begin{array}{c}0.895 \\
(0.009)\end{array}$ & *** & $\begin{array}{c}0.896 \\
(0.010)\end{array}$ & $* * *$ & $\begin{array}{c}0.894 \\
(0.009)\end{array}$ & \\
\hline Obs. & 2466 & & 2466 & & 2466 & & 2466 & & 2466 & & 2466 & \\
\hline Adj. $R^{2}$ & 0.152 & & 0.150 & & 0.157 & & 0.787 & & 0.788 & & 0.808 & \\
\hline$A I C$ & 3.133 & & 3.137 & & 3.135 & & 3.348 & & 3.349 & & 3.351 & \\
\hline Newey-West Lags & 8 & & 8 & & 8 & & 3 & & 2 & & 3 & \\
\hline F-statistic & 63.94 & & 40.60 & & 30.62 & & 1482.7 & & 228.30 & & 691.95 & \\
\hline
\end{tabular}

This table presents regression results with returns in the gold futures market during period $t\left(R_{t}\right)$ as the dependent variable in columns $1,2 \& 3$, and the log of trading volumes during period $t\left(\log \left(\right.\right.$ volume $\left.\left._{t}\right)\right)$ in columns $4,5 \& 6$. The News variable is News_Ave. News is also disaggregated into positive $\left(+N e w s_{t}\right)$ and negative $\left(-N e w s_{t}\right)$ components. A set of dummy variables is included $\left\{S L_{t}, S S_{t}, H L_{t}, H S_{t}\right\}$ which take a value of 1 if the COT data indicates the positions of speculators $(S)$ or hedgers $(H)$ are in the highest quintile (Long - $L$ ) or the lowest quintile (Short $-S$ ) and 0 otherwise. There is a series of interaction variables between news sentiment and trader net position. Newey-West standard errors are shown in parantheses, with the appropriate number of lags in each case determined using Akaike Information Criterion (AIC). ${ }^{* * *},{ }^{* *}$, and ${ }^{*}$ denote significance at the $1 \%, 5 \%$ and $10 \%$ levels respectively. 
Table 6

Variation of news sentiment and net trader position with business cycle

\begin{tabular}{|c|c|c|c|c|c|c|c|c|c|c|c|c|}
\hline & $\begin{array}{c}(1) \\
\text { News_Ave }{ }_{t}\end{array}$ & & $\begin{array}{c}\text { (2) } \\
\text { News_Ave }{ }_{t}\end{array}$ & & $\begin{array}{c}\text { (3) } \\
\text { Speculator }_{t}\end{array}$ & & $\begin{array}{c}(4) \\
\text { Speculator }_{t}\end{array}$ & & $\begin{array}{c}\text { (5) } \\
\text { Hedger }_{t}\end{array}$ & & $\begin{array}{c}(6) \\
\text { Hedger }_{t}\end{array}$ & \\
\hline Constant & $\begin{array}{c}0.016 \\
(0.007)\end{array}$ & $* *$ & $\begin{array}{c}0.008 \\
(0.006)\end{array}$ & & $\begin{array}{c}1.762 \\
(0.131)\end{array}$ & *** & $\begin{array}{c}1.797 \\
(0.110)\end{array}$ & *** & $\begin{array}{c}-2.372 \\
(0.202)\end{array}$ & *** & $\begin{array}{l}-2.362 \\
(0.055)\end{array}$ & *** \\
\hline$\% \Delta$ Yield (3m T-Bill) & & & $\begin{array}{c}0.0003 \\
(0.0009)\end{array}$ & & & & $\begin{array}{l}-0.0001 \\
(0.0004)\end{array}$ & & & & $\begin{array}{c}0.0001 \\
(0.0006)\end{array}$ & \\
\hline$\% \Delta$ Credit Spread & & & $\begin{array}{l}-0.004 \\
(0.001)\end{array}$ & $* * *$ & & & $\begin{array}{l}-0.012 \\
(0.006)\end{array}$ & $* *$ & & & $\begin{array}{c}0.023 \\
(0.011)\end{array}$ & $* *$ \\
\hline$\% \Delta$ Dividend Yield & & & $\begin{array}{l}-0.003 \\
(0.002)\end{array}$ & $*$ & & & $\begin{array}{l}-0.008 \\
(0.008)\end{array}$ & & & & $\begin{array}{c}0.007 \\
(0.012)\end{array}$ & \\
\hline Recession $_{t}$ & $\begin{array}{l}-0.044 \\
(0.010)\end{array}$ & $* *$ & & & $\begin{array}{c}0.186 \\
(0.083)\end{array}$ & $* *$ & & & $\begin{array}{c}0.063 \\
(0.029)\end{array}$ & $* *$ & & \\
\hline Obs. & 2468 & & 2460 & & 2468 & & 2460 & & 2468 & & 2460 & \\
\hline Adj. $R^{2}$ & 0.027 & & 0.007 & & 0.011 & & 0.012 & & 0.001 & & 0.019 & \\
\hline$A I C$ & 2.07 & & 2.07 & & 2.08 & & 2.09 & & 2.69 & & 2.70 & \\
\hline Newey-West Lags & 6 & & 4 & & 6 & & 3 & & 6 & & 5 & \\
\hline F-statistic & 67.68 & & 5.73 & & 26.66 & & 2.15 & & 1.68 & & 11.86 & \\
\hline
\end{tabular}

This table presents regression results with measures of news sentiment and net trader position (normalized by inventory levels) as the dependent variable. A series of macroeconomic variables are included in the regression to indicate the condition of the business cycle during period $t$; percentage changes in yields, credit spreads and dividend yields. In addition there is a dummy variable indicating whether the economy is in recession during period $t\left(R_{e c e s s i o n}\right)$. NeweyWest standard errors are shown in parantheses, with the appropriate number of lags in each case determined using Akaike Information Criterion (AIC). ${ }^{* * *}$, ${ }^{* *}$ and * denote significance at the $1 \%, 5 \%$ and $10 \%$ levels respectively. 
Table 7

Influence of recession on the news sentiment / gold return relationship

\begin{tabular}{|c|c|c|c|c|c|c|c|c|c|c|c|c|}
\hline & $\begin{array}{l}(1) \\
R_{t}\end{array}$ & & $\begin{array}{l}(2) \\
R_{t}\end{array}$ & & $\begin{array}{l}(3) \\
R_{t}\end{array}$ & & $\begin{array}{l}(4) \\
R_{t}\end{array}$ & & $\begin{array}{l}(5) \\
R_{t}\end{array}$ & & $\begin{array}{l}(6) \\
R_{t}\end{array}$ & \\
\hline Constant & $\begin{array}{l}-0.005 \\
(0.029)\end{array}$ & & $\begin{array}{c}0.060 \\
(0.061)\end{array}$ & * & $\begin{array}{l}-0.026 \\
(0.065)\end{array}$ & & $\begin{array}{c}0.079 \\
(0.062)\end{array}$ & & $\begin{array}{l}-0.017 \\
(0.063)\end{array}$ & & $\begin{array}{c}0.062 \\
(0.063)\end{array}$ & \\
\hline $\mathrm{News}_{t}$ & $\begin{array}{c}4.392 \\
(0.384)\end{array}$ & $* * *$ & & & $\begin{array}{c}4.588 \\
(0.361)\end{array}$ & $* * *$ & & & $\begin{array}{c}4.482 \\
(0.376)\end{array}$ & $* * *$ & & \\
\hline $\mid-$ News $_{t} \mid$ & & & $\begin{array}{l}-5.240 \\
(0.821)\end{array}$ & $* * *$ & & & $\begin{array}{l}-6.015 \\
(0.714)\end{array}$ & $* * *$ & & & $\begin{array}{l}-5.603 \\
(0.778)\end{array}$ & *** \\
\hline+ News $_{t}$ & & & $\begin{array}{c}3.645 \\
(0.407)\end{array}$ & $* * *$ & & & $\begin{array}{c}3.418 \\
(0.394)\end{array}$ & $* * *$ & & & $\begin{array}{c}3.575 \\
(0.396)\end{array}$ & *** \\
\hline Recession $_{t}$ & $\begin{array}{c}0.253 \\
(0.099)\end{array}$ & ** & $\begin{array}{c}0.380 \\
(0.123)\end{array}$ & $* * *$ & & & & & $\begin{array}{c}0.169 \\
(0.094)\end{array}$ & $*$ & $\begin{array}{c}0.351 \\
(0.136)\end{array}$ & ** \\
\hline High Credit Spread $_{t}$ & & & & & $\begin{array}{c}0.253 \\
(0.088)\end{array}$ & $* * *$ & $\begin{array}{c}0.236 \\
(0.120)\end{array}$ & ** & $\begin{array}{c}0.130 \\
(0.130)\end{array}$ & & $\begin{array}{c}0.053 \\
(0.114)\end{array}$ & \\
\hline News $_{t}{ }^{*}$ Recession $_{t}$ & $\begin{array}{c}2.786 \\
(0.917)\end{array}$ & *** & & & & & & & $\begin{array}{c}2.829 \\
(1.289)\end{array}$ & ** & & \\
\hline News $_{t}{ }^{*}$ High Credit Spread $_{t}$ & & & & & $\begin{array}{c}1.589 \\
(0.788)\end{array}$ & ** & & & $\begin{array}{l}-0.184 \\
(1.157)\end{array}$ & & & \\
\hline $\mid-$ News $_{t} /{ }^{*}$ Recession $_{t}$ & & & $\begin{array}{l}-3.741 \\
(1.401)\end{array}$ & $* * *$ & & & & & & & $\begin{array}{l}-4.426 \\
(1.916)\end{array}$ & ** \\
\hline+ News $_{t}{ }^{*}$ Recession $_{t}$ & & & $\begin{array}{c}0.567 \\
(2.366)\end{array}$ & & & & & & & & $\begin{array}{c}0.743 \\
(2.735)\end{array}$ & \\
\hline $\mid$ News $_{t} \mid{ }^{*}$ High Credit Spread ${ }_{t}$ & & & & & & & $\begin{array}{l}-2.909 \\
(1.446)\end{array}$ & ** & & & $\begin{array}{l}-1.441 \\
(1.693)\end{array}$ & \\
\hline+ News $_{t}{ }^{*}$ High Credit Spread $_{t}$ & & & & & & & $\begin{array}{c}1.467 \\
(2.364)\end{array}$ & & & & $\begin{array}{c}1.234 \\
(2.612)\end{array}$ & \\
\hline$R_{t-1}$ & $\begin{array}{l}-0.084 \\
(0.019)\end{array}$ & $* * *$ & $\begin{array}{l}-0.084 \\
(0.019)\end{array}$ & $* * *$ & $\begin{array}{l}-0.083 \\
(0.019)\end{array}$ & $* * *$ & $\begin{array}{l}-0.083 \\
(0.019)\end{array}$ & $* * *$ & $\begin{array}{l}-0.085 \\
(0.020)\end{array}$ & $* * *$ & $\begin{array}{l}-0.086 \\
(0.019)\end{array}$ & *** \\
\hline Day & $\begin{array}{c}0.003 \\
(0.019)\end{array}$ & & $\begin{array}{c}0.003 \\
(0.018)\end{array}$ & & $\begin{array}{c}0.007 \\
(0.020)\end{array}$ & & $\begin{array}{c}0.005 \\
(0.020)\end{array}$ & & $\begin{array}{c}0.003 \\
(0.019)\end{array}$ & & $\begin{array}{c}0.002 \\
(0.019)\end{array}$ & \\
\hline Obs. & 2466 & & 2466 & & 2466 & & 2466 & & 2466 & & 2466 & \\
\hline $\operatorname{Adj} . R^{2}$ & 0.154 & & 0.157 & & 0.151 & & 0.154 & & 0.155 & & 0.158 & \\
\hline AIC & 3.129 & & 3.126 & & 3.134 & & 3.131 & & 3.130 & & 3.127 & \\
\hline Newey-West Lags & 6 & & 6 & & 6 & & 6 & & 6 & & 5 & \\
\hline F-statistic & 91.07 & & 66.66 & & 88.59 & & 64.93 & & 65.55 & & 47.30 & \\
\hline
\end{tabular}

This table presents regression results from equation (4) with returns in the gold futures market during period $t\left(R_{t}\right)$ as the dependent variable. The News variable is News_Ave. News is also disaggregated into positive $\left(+N e w s_{t}\right)$ and negative $\left(-N e w s_{t}\right)$ components. There is a dummy variable indicating whether the economy is in recession during period $t\left(\right.$ Recession $\left._{t}\right)$, or whether credit spreads are in the top quintile and classified as high $\left(\right.$ High Credit Spread $\left._{t}\right)$. A series of interaction variables between news sentiment, recession, and high credit spread are also included. Newey-West standard errors are shown in parantheses, with the appropriate number of lags determined using Akaike Information Criterion (AIC). ${ }^{* * *},{ }^{* *}$, and ${ }^{*}$ denote significance at the $1 \%, 5 \%$ and $10 \%$ levels respectively. 
Table 8

Influence of extreme market positioning on the news sentiment / return relationship

\begin{tabular}{|c|c|c|c|c|c|c|c|c|}
\hline & $\begin{array}{l}(1) \\
R_{t}\end{array}$ & & $\begin{array}{l}(2) \\
R_{t}\end{array}$ & & $\begin{array}{l}(3) \\
R_{t}\end{array}$ & & $\begin{array}{l}(4) \\
R_{t}\end{array}$ & \\
\hline Constant & $\begin{array}{c}0.180 \\
(0.039)\end{array}$ & *** & $\begin{array}{c}0.139 \\
(0.040)\end{array}$ & **** & $\begin{array}{c}0.180 \\
(0.038)\end{array}$ & *** & $\begin{array}{c}0.151 \\
(0.039)\end{array}$ & *** \\
\hline$+\mathrm{NeWs}_{t}$ & $\begin{array}{c}0.040 \\
(0.006)\end{array}$ & $* * *$ & $\begin{array}{c}3.469 \\
(0.444)\end{array}$ & $* * *$ & $\begin{array}{c}0.037 \\
(0.007)\end{array}$ & $* * *$ & $\begin{array}{c}3.287 \\
(0.490)\end{array}$ & *** \\
\hline$-\mathrm{News}_{t}$ & $\begin{array}{c}0.066 \\
(0.005)\end{array}$ & $* * *$ & $\begin{array}{c}6.604 \\
(0.459)\end{array}$ & $* * *$ & $\begin{array}{c}0.060 \\
(0.006)\end{array}$ & $* * *$ & $\begin{array}{c}6.451 \\
(0.519)\end{array}$ & *** \\
\hline$S L_{\mathrm{t}}$ & $\begin{array}{l}-0.142 \\
(0.130)\end{array}$ & & $\begin{array}{l}-0.127 \\
(0.126)\end{array}$ & & & & & \\
\hline$S S_{\mathrm{t}}$ & $\begin{array}{l}-0.347 \\
(0.098)\end{array}$ & $* * *$ & $\begin{array}{l}-0.316 \\
(0.095)\end{array}$ & $* * *$ & & & & \\
\hline$H L_{\mathrm{t}}$ & $\begin{array}{c}0.376 \\
(0.099)\end{array}$ & $* * *$ & $\begin{array}{c}0.527 \\
(0.097)\end{array}$ & $* * *$ & & & & \\
\hline$H S_{\mathrm{t}}$ & $\begin{array}{c}0.127 \\
(0.130)\end{array}$ & & $\begin{array}{c}0.122 \\
(0.127)\end{array}$ & & & & & \\
\hline$+{ }^{N}$ ewst ${ }^{*} S L t$ & & & & & $\begin{array}{l}-0.011 \\
(0.019)\end{array}$ & & $\begin{array}{l}-0.996 \\
(1.344)\end{array}$ & \\
\hline$+{ }^{N}$ ewst ${ }^{*} S S t$ & & & & & $\begin{array}{l}-0.036 \\
(0.024)\end{array}$ & & $\begin{array}{l}-2.344 \\
(1.391)\end{array}$ & $*$ \\
\hline$+{ }^{N}$ ewst ${ }^{*} H L t$ & & & & & $\begin{array}{c}0.089 \\
(0.031)\end{array}$ & $* * *$ & $\begin{array}{c}5.123 \\
(1.658)\end{array}$ & $* * *$ \\
\hline$+{ }_{+}$Newst ${ }^{*} H S t$ & & & & & $\begin{array}{c}0.018 \\
(0.019)\end{array}$ & & $\begin{array}{c}1.078 \\
(1.348)\end{array}$ & \\
\hline$-N e w s t^{*} S L t$ & & & & & $\begin{array}{c}0.062 \\
(0.040)\end{array}$ & & $\begin{array}{c}4.105 \\
(2.682)\end{array}$ & \\
\hline$-N e w s t^{*} S S t$ & & & & & $\begin{array}{c}0.047 \\
(0.018)\end{array}$ & $* * *$ & $\begin{array}{c}2.555 \\
(1.117)\end{array}$ & ** \\
\hline$-N e w s t^{*} H L t$ & & & & & $\begin{array}{l}-0.011 \\
(0.015)\end{array}$ & $* * *$ & $\begin{array}{l}-2.732 \\
(0.993)\end{array}$ & $* * *$ \\
\hline -Newst ${ }^{*} H S t$ & & & & & $\begin{array}{l}-0.047 \\
(0.039)\end{array}$ & & $\begin{array}{l}-4.018 \\
(2.843)\end{array}$ & \\
\hline$R_{t-1}$ & $\begin{array}{l}-0.063 \\
(0.019)\end{array}$ & $* * *$ & $\begin{array}{l}-0.085 \\
(0.019)\end{array}$ & $* * *$ & $\begin{array}{l}-0.063 \\
(0.019)\end{array}$ & $* * *$ & $\begin{array}{l}-0.084 \\
(0.019)\end{array}$ & $* * *$ \\
\hline $\begin{array}{l}\text { Adj. } R^{2} \\
\text { F-statistic }\end{array}$ & $\begin{array}{l}0.111 \\
45.01\end{array}$ & & $\begin{array}{l}0.157 \\
66.71\end{array}$ & & $\begin{array}{l}0.115 \\
28.88\end{array}$ & & $\begin{array}{l}0.153 \\
41.34\end{array}$ & \\
\hline
\end{tabular}

This table presents regression results with returns in the gold futures market during period $t$ $\left(R_{t}\right)$ as the dependent variable. In column $1 \& 3$ the News variable is News_Sum, while in column $2 \& 4$ the News variable is News_Ave. News is also disaggregated into positive $\left(+{ }^{N e w s_{t}}\right)$ and negative $\left(-\right.$ News $\left._{t}\right)$ components. A set of dummy variables is included $\left\{S L_{t}, S S_{t}\right.$, $\left.H L_{t}, H S_{t}\right\}$ which take a value of 1 if the COT data indicates the positions of speculators $(S)$ or hedgers $(H)$ are in the highest decile (Long - $L$ ) or the lowest decile (Short - $S$ ) and 0 otherwise. . There is a series of interaction variables between news sentiment and trader net position. Standard errors are shown in parantheses. ${ }^{* *},{ }^{* *}$, and * denote significance at the $1 \%$, $5 \%$ and $10 \%$ levels respectively. 
Table 9

\begin{tabular}{|c|c|c|c|c|c|c|c|c|c|c|c|c|c|c|c|c|c|c|c|c|c|c|c|}
\hline & & & & & & & & & & ders ability to predi & ct ne & ws sentiment & & & & & & & & & & & \\
\hline & $\begin{array}{c}(1) \\
\text { News Sum }\end{array}$ & & $\begin{array}{c}(2) \\
\text { News Sum }\end{array}$ & & $\begin{array}{c}\text { (3) } \\
\text { News Sum }\end{array}$ & & $\begin{array}{c}(4) \\
\text { News Sum }\end{array}$ & & $\begin{array}{c}\text { (5) } \\
\text { News Sum }\end{array}$ & $\begin{array}{c}\text { (6) } \\
\text { News Sum }\end{array}$ & & $\begin{array}{c}(7) \\
\text { News Avg }\end{array}$ & & $\begin{array}{c}(8) \\
\text { News Avg }\end{array}$ & & $\begin{array}{c}\text { (9) } \\
\text { News Avg }\end{array}$ & & $\begin{array}{c}(10) \\
\text { News Avg }\end{array}$ & & $\begin{array}{c}(11) \\
\text { News Avg }\end{array}$ & & $\begin{array}{c}(12) \\
\text { News Avg. }\end{array}$ & \\
\hline Constant & $\begin{array}{l}-5.302 \\
(0.404)\end{array}$ & $* * *$ & $\begin{array}{l}-6.444 \\
(0.409)\end{array}$ & *** & $\begin{array}{l}-1.135 \\
(0.167)\end{array}$ & $* * *$ & $\begin{array}{l}-0.492 \\
(0.167)\end{array}$ & *** & $\begin{array}{l}-0.214 \\
(0.166)\end{array}$ & $\begin{array}{l}-1.127 \\
(0.167)\end{array}$ & ${ }^{* * *}$ & $\begin{array}{l}-0.054 \\
(0.005)\end{array}$ & ${ }^{* * *}$ & $\begin{array}{l}-0.063 \\
(0.005)\end{array}$ & $* * *$ & $\begin{array}{c}0.003 \\
(0.002)\end{array}$ & & $\begin{array}{c}0.012 \\
(0.002)\end{array}$ & ${ }^{* * *}$ & $\begin{array}{c}0.016 \\
(0.002)\end{array}$ & $* * *$ & $\begin{array}{l}0.003 \\
(0.002)\end{array}$ & \\
\hline Speculator $_{\mathrm{t}}$ & $\begin{array}{c}1.352 \\
(0.110)\end{array}$ & $* * *$ & & & & & & & & & & $\begin{array}{c}0.018 \\
(0.001)\end{array}$ & $* * *$ & & & & & & & & & & \\
\hline Hedger $_{\mathrm{t}}$ & & & $\begin{array}{l}-1.283 \\
(0.085)\end{array}$ & $* * *$ & & & & & & & & & & $\begin{array}{l}-0.016 \\
(0.001)\end{array}$ & $* * *$ & & & & & & & & \\
\hline$S L_{\mathrm{t}}$ & & & & & $\begin{array}{c}4.363 \\
(0.521)\end{array}$ & $* * *$ & & & & & & & & & & $\begin{array}{c}0.052 \\
(0.007)\end{array}$ & *** & & & & & & \\
\hline$S S_{\mathrm{t}}$ & & & & & & & $\begin{array}{l}-1.918 \\
(0.528)\end{array}$ & *** & & & & & & & & & & $\begin{array}{l}-0.039 \\
(0.007)\end{array}$ & $* * *$ & & & & \\
\hline$H L_{\mathrm{t}}$ & & & & & & & & & $\begin{array}{l}-4.630 \\
(0.521)\end{array}$ & $* * *$ & & & & & & & & & & $\begin{array}{l}-0.076 \\
(0.007)\end{array}$ & $* * *$ & & \\
\hline$H S_{\mathrm{t}}$ & & & & & & & & & & $\begin{array}{c}4.354 \\
(0.524)\end{array}$ & *** & & & & & & & & & & & $\begin{array}{c}0.052 \\
(0.007)\end{array}$ & $* * *$ \\
\hline $\operatorname{Adj} . R^{2}$ & 0.059 & & 0.086 & & 0.028 & & 0.005 & & 0.031 & 0.027 & & 0.061 & & 0.076 & & 0.023 & & 0.005 & & 0.049 & & 0.023 & \\
\hline F-statistic & 152.37 & & 229.87 & & 70.23 & & 13.17 & & 79.12 & 68.93 & & 158.91 & & 201.43 & & 57.23 & & 13.17 & & 127.41 & & 56.51 & \\
\hline
\end{tabular}

This table presents regression results with news sentiment as the dependent variable. In columns 1 - 6 the dependent News variable is News Sum, while in column 7-12 the News variable is News Ave. Speculator $f_{t}$ and Hedger ${ }_{t}$ reflect the net

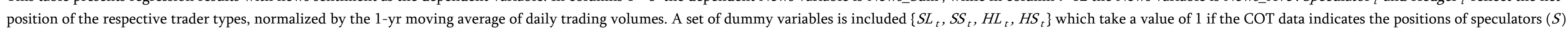
or hedgers $(H)$ are in the highest decile (Long $-L$ ) or the lowest decile (Short $-S$ ) and 0 otherwise. . There is a series of interaction variables between news sentiment and trader net position. Standard errors are shown in parantheses. ${ }^{* * *}, * *$, and ${ }^{*}$ denote significance at the $1 \%, 5 \%$ and $10 \%$ levels respectively. 